\title{
Disruption of the Blood-Brain Barrier During Neuroinflammatory and Neuroinfectious Diseases
}

\author{
Hamid Salimi and Robyn S. Klein
}

\begin{abstract}
As the organ of highest metabolic demand, utilizing over $25 \%$ of total body glucose utilization via an enormous vasculature with one capillary every $73 \mu \mathrm{m}$, the brain evolves a barrier at the capillary and postcapillary venules to prevent toxicity during serum fluctuations in metabolites and hormones, to limit brain swelling during inflammation, and to prevent pathogen invasion. Understanding of neuroprotective barriers has since evolved to incorporate the neurovascular unit (NVU), the blood-cerebrospinal fluid (CSF) barrier, and the presence of CNS lymphatics that allow leukocyte egress. Identification of the cellular and molecular participants in BBB function at the NVU has allowed detailed analyses of mechanisms that contribute to $\mathrm{BBB}$ dysfunction in various disease states, which include both autoimmune and infectious etiologies. This chapter will introduce some of the cellular and molecular components that promote barrier function but may be manipulated by inflammatory mediators or pathogens during neuroinflammation or neuroinfectious diseases.
\end{abstract}

Keywords Blood-brain barrier · Neuroinfectious diseases · Tight junctions · Innate immunity $\cdot$ Central nervous system

\footnotetext{
H. Salimi

Departments of Medicine, Washington University School of Medicine, St. Louis, MO, USA

R. S. Klein $(\square)$

Departments of Medicine, Washington University School of Medicine, St. Louis, MO, USA

Departments of Pathology and Immunology, Washington University School of Medicine,

St. Louis, MO, USA

Departments of Neuroscience, Washington University School of Medicine,

St. Louis, MO, USA

Division of Biology and Biomedical Sciences, Center for Neuroimmunology \& Neuroinfectious Diseases, Washington University School of Medicine, St. Louis, MO, USA e-mail: rklein@wustl.edu
} 


\section{Abbreviations}

\begin{tabular}{|c|c|}
\hline AJ & Adherens junction \\
\hline ANG-1 & Angiopoietin-1 \\
\hline APC & Antigen-presenting cell \\
\hline AQP4 & Aquaporin 4 \\
\hline $\mathrm{BBB}$ & Blood-brain barrier \\
\hline bFGF & Basic fibroblast growth factor \\
\hline BMEC & Brain microvascular endothelial cell \\
\hline Cav-1 & Caveolin-1 \\
\hline $\mathrm{CBF}$ & Cerebral blood flow \\
\hline CHIKV & Chikungunya virus \\
\hline CNS & Central nervous system \\
\hline $\mathrm{CSF}$ & Cerebrospinal fluid \\
\hline CSPG & Chondroitin sulfate proteoglycan \\
\hline CTL & Cytotoxic T cell \\
\hline DP1 & Prostaglandin D2 receptor 1 \\
\hline dsRNA & Double-stranded ribonucleic acid \\
\hline $\mathrm{EC}$ & Endothelial cell \\
\hline ECM & Experimental cerebral malaria \\
\hline $\mathrm{ECM}$ & Extracellular matrix \\
\hline ERK & Extracellular signal-regulated protein kinase \\
\hline ET & Edema toxin \\
\hline gd-MRI & Gadolinium MRI \\
\hline GDNF & Glial cell line-derived neurotrophic factor \\
\hline $\mathrm{HiV}$ & Hendra virus \\
\hline HIV-1 & Human immunodeficiency virus type 1 \\
\hline HSV & Herpes simplex virus \\
\hline ICAM-1 & Intercellular adhesion molecule 1 \\
\hline IFN & Interferon \\
\hline IFNAR & Type I IFN receptor \\
\hline IL & Interleukin \\
\hline $\mathrm{iRBC}$ & Infected RBC \\
\hline JEV & Japanese encephalitis virus \\
\hline LCMV & Lymphocytic choriomeningitis virus \\
\hline MAPK & Mitogen-activated protein kinase \\
\hline MAV-1 & Mouse adenovirus type-1 \\
\hline MAVS & Mitochondrial antiviral-signaling protein \\
\hline MDA5 & Melanoma differentiation factor 5 \\
\hline MerTK & Tyrosine-protein kinase Mer \\
\hline Mfsd2a & Major facilitator superfamily domain-containing protein $2 \mathrm{a}$ \\
\hline MHV & Mouse hepatitis virus \\
\hline MMP & Matrix metalloproteinase \\
\hline MRI & Magnetic resonance imaging \\
\hline
\end{tabular}




$\begin{array}{ll}\text { MS } & \text { Multiple sclerosis } \\ \text { Msp } & \text { Meningococcal serine protease } \\ \text { NADPH } & \text { Nicotinamide adenine dinucleotide phosphate } \\ \text { NiV } & \text { Nipah virus } \\ \text { NLR } & \text { Nucleotide oligomerization domain-like receptor } \\ \text { NMOSD } & \text { Neuromyelitis optica spectrum disorder } \\ \text { NVU } & \text { Neurovascular unit } \\ \text { OPN } & \text { Osteopontin } \\ \text { PAFR } & \text { Platelet-activating factor receptor } \\ \text { PDGF-BB } & \text { Platelet-derived growth factor BB } \\ \text { PDGFR } \beta & \text { Platelet-derived growth factor receptor } \beta \\ \text { PECAM-1 } & \text { Platelet-associated cell adhesion molecule 1 } \\ \text { PG } & \text { Proteoglycan } \\ \text { PGD2 } & \text { Prostaglandin D2 } \\ \text { PI3K } & \text { Phosphatidylinositol 3 kinase } \\ \text { pIgR } & \text { Polymeric immunoglobulin receptor } \\ \text { PKB } & \text { Protein kinase B } \\ \text { PLC } & \text { Phospholipase C } \\ \text { PPMS } & \text { Primary progressive multiple sclerosis } \\ \text { PRR } & \text { Pattern recognition receptor } \\ \text { RABV } & \text { Rabies virus } \\ \text { Rac-1 } & \text { Ras-related C3 botulinum toxin substrate } \\ \text { RBC } & \text { Red blood cell } \\ \text { RhoA } & \text { Ras homolog gene family, member A } \\ \text { RLR } & \text { Retinoic acid-inducible gene 1 like receptor } \\ \text { ROS } & \text { Reactive oxygen species } \\ \text { RRMS } & \text { Recovery and remission multiple sclerosis } \\ \text { S1P } & \text { Sphingosine-1-phosphate } \\ \text { SAS } & \text { Subarachnoid space } \\ \text { sCD40L } & \text { Soluble CD40L } \\ \text { SHH } & \text { Sonic hedgehog } \\ \text { SPMS } & \text { Secondary-progressive multiple sclerosis } \\ \text { ssRNA } & \text { Single-stranded ribonucleic acid } \\ \text { TBEV } & \text { Tick-borne encephalitic virus } \\ \text { TEER } & \text { Transendothelial electrical resistance } \\ \text { TIMP } & \text { Endogenous tissue inhibitor of MMP } \\ \text { TJ } & \text { Tight junction } \\ \text { TLR } & \text { Toll-like receptor } \\ \text { TMEV } & \text { Theiler's murine encephalitis virus } \\ \text { TNFo } & \text { Tumor necrosis factor alpha } \\ \text { VCAM-1 } & \text { Vascular cell adhesion molecule 1 } \\ \text { VEEV } & \text { Venezuelan equine encephalitis virus } \\ \text { VEGF } & \text { Vascular endothelial growth factor } \\ \text { VSV } & \text { Vesicular stomatitis virus } \\ \text { WNV } & \text { West Nile virus } \\ & \end{array}$




\section{Introduction to BBB Structure and Function}

Over 100 years ago, a publication by Lina Stern, Professor and Head of the Department of Physiological Chemistry at the University of Geneva, coined the term "blood-brain barrier (BBB)" to describe the finding that systemically administered dyes are excluded from the developing mammalian brain [1]. Since then, physicians and scientists have appreciated the unique diffusion barrier between the blood and the brain and its stringent regulation of central nervous system (CNS) entry of molecules, immune cells, and pathogens [2-4]. The BBB occurs at the level of postcapillary venules and capillaries and is comprised of a variety of physical specializations including inter-endothelial tight and adherens junctions (TJ and AJ), endothelial cells with polarized expression of protein receptor influx and efflux transporters, and transcytosis systems limited to albumen and histones [5]. Vasculature at the BBB is enveloped by pericytes and astrocyte end feet, which leads to the development of dual basement membranes with a complicated extracellular matrix (ECM) separating blood contents from perivascular spaces within the CNS parenchyma. The CNS ECM is comprised of hyaluronic acid and proteoglycans (PG), mainly chondroitin sulfate proteoglycans (CSPG) [6]. Heparan sulfate proteoglycans (HSPG), especially the negatively charged heparan sulfate (HS), bind and sequester pro-inflammatory molecules, including the endothelial cell-derived chemokine CXCL12 ([7] and see below), which regulates the recruitment and effector functions of leukocytes that infiltrate the CNS during neuroinflammatory diseases [8]. BBB TJ are heterodimeric proteins comprised of occludin and members of the claudin family of proteins, including claudin-3 or -5 , that link to the cytoskeleton via the scaffolding and regulatory proteins ZO-1, -2, -3, and cingulin (reviewed in [9]). Similarly, AJ are comprised of E-cadherin proteins that link to actin filaments via $\alpha-, \beta$-, and $\gamma$-catenin. The length of actin fibers, which are regulated by the activation of RhoGTPases, controls the integrity of both AJ and TJ complexes [10]. Activation of Rac1 promotes stabilization of TJ and AJ, while RhoA promotes destabilization. Junctional integrity is critical for two separate capacities of the BBB, termed "gate" and "fence" function [11]. Gate function refers to the importance of inter-endothelial junctional complexes in limiting the movement of molecules and cells from the blood to the brain parenchyma. RhoA activation may therefore reduce gate function and allow $\mathrm{BBB}$ penetration without loss of junctional proteins. Fence function refers to the role of $\mathrm{TJ}$ and $\mathrm{AJ}$ in the maintenance of BBB polarity, preventing the rotation and diffusion of proteins and other biomolecules within the cell membrane between abluminal and luminal surfaces. Thus, BBB permeability can also be increased without complete destruction of junctional proteins through alterations in the locations of proteins involved in transport or transcytosis.

The transcellular transport of macromolecules across endothelial barriers occurs in peripheral organs via a variety of pathways including macropinocytosis and clathrin- and caveolae-mediated endocytosis. The BBB, however, exhibits low levels of macropinocytosis and lack of clathrin expression. Caveolae-mediated 
transcytosis is strictly regulated at the BBB by the major facilitator superfamily domain-containing protein $2 \mathrm{a}$ (Mfsd2a), which is exclusively expressed on brain endothelial cells and induced by pericytes [12]. Consistently, $M f s d 2 a^{-/-}$mice exhibit increased BBB permeability, caused by enhanced caveolae-mediated transcytosis [12]. Caveolae are flask-shaped plasma membrane invagination enriched in cholesterol and sphingolipids. They contain the major structural protein caveolin-1 (Cav1), which undergoes extensive oligomerization prior to interacting with cavin-1 to form caveolae. Genetic ablation of either Cav-1 or cavin-1 results in a complete loss of caveolae in related tissues, suggesting their essential role in caveolae formation $[13,14]$. Previous studies identified a close association between caveolae and stress fibers, a feature absent in clathrin-coated vesicles [15]. These interactions are critical for both stabilizing and entry of caveolae at the plasma membrane and are also regulated by the small RhoGTPases, including Ras homolog gene family, member A (RhoA) and Ras-related C3 botulinum toxin substrate (Rac)-1 [15]. Caveolae internalization is further regulated by kinases and phosphatases. In general, BBB endothelial cells exhibit low level of formation of caveolae due to the effects of Mfsd2a. However, levels of this protein are decreased during intracranial hemorrhage, suggesting that serum inflammatory mediators might increase BBB permeability via their effects on caveolae-mediated transcytosis.

The polarized expression of proteins at the CNS vascular barriers is also important for normal immune surveillance of the CNS. There is a growing body of evidence that lymphocytes, including effector memory CD4 and CD8 T cells, normally reside within the cerebrospinal fluid (CSF) compartment [16-22]. The CSF compartment includes both the subarachnoid space (SAS) and the ventricular system, the latter of which contains the choroid plexus, a plexus of microvessels with modified ependymal cells that form a barrier between its fenestrated capillaries and the CSF compartment (reviewed in [23]), which connects with lymphatics that provide mechanisms for leukocyte egress out of the CNS [24, 25]. The choroid plexus is the main producer of CSF, which circulates via a combination of directed bulk flow, and both pulsatile and continuous bidirectional movement at the BBB and at the borders between CSF and CNS interstitial spaces (reviewed in [26]). The SAS occurs between meningeal arachnoid and pia maters and contains fenestrated capillaries where immune cells may exit the blood and migrate along abluminal surfaces into perivascular spaces within the brain parenchyma at sites with BBB specializations. The localization of lymphocytes along CNS vasculature is accomplished via polarized expression of chemokines, including CXCL12 [27], which promotes interactions between $\mathrm{T}$ and perivascular antigen-presenting cells (APCs) in the setting of neuroinfectious diseases. Infiltrating $\mathrm{T}$ cells express CXCR4, a $\mathrm{G}$ protein-coupled signaling receptor of CXCL12 that is downregulated after $\mathrm{T}$ cell receptor activation, which allows $\mathrm{T}$ cell egress out of perivascular compartments [28, 29]. The abluminal localization of CXCL12 stands in stark contrast to its expression pattern at high endothelial venules within lymph nodes, where luminal CXCL12 promotes the homeostatic circulation of lymphocytes between the blood and lymphoid compartments [30], whereas BBB CXCL12 instead limits T cell entry into the CNS parenchyma $[27,28]$. The level of CNS expression of CXCL12 vascular barriers is 
accomplished at both transcriptional and protein expression levels, the latter of which occurs via the CXCL12 scavenging receptor CXCR7 [31]. As the CXCR7 promoter contains eight NF-kB binding sites, multiple cytokines may alter the level of its expression at the BBB during neuroinflammation, including interleukin- $1,-8$, -17 , and interferon- $\gamma$. Alterations in the patterns of localizing cues at the BBB could promote excessive leukocyte entry, which may lead to further alterations in the BBB functions.

\section{Cellular Constituents of the NVU Regulate BBB Formation and Function}

The NVU is comprised of brain microvascular endothelial cells (BMECs), abluminal pericytes, and astrocyte terminal processes, known as end feet, the latter of which receive neuronal signals that modulate BBB influx and efflux transporters in response to parenchymal demands or damage [5]. Pericapillary pericytes extend their processes along pre- and postcapillary vessels, receiving signals from BMECs, astrocytes, and neurons that induce them to form, maintain, and regulate BBB function [32]. Studies in pericyte-deficient and transgenic mice with aberrant signaling between endothelial-derived platelet-derived growth factor BB (PDGF-BB) and platelet-derived growth factor receptor $\beta$ (PDGFR $\beta$ ) in pericytes have thus identified critical roles for these cells from embryonic development to adulthood [33]. $P d g f b$ and $P d g f r \beta$ homozygous knockout mice completely lack pericytes, which causes embryonic lethality via cerebral blood vessel rupture and microhemorrhages. While $P d g f r \beta^{+/-}$mice and mice with modified PDGF-BB bioavailability are viable, they exhibit reductions in pericyte coverage along vasculature, leading to poor maintenance of BBB function and increased permeability [33]. These mice also exhibit dysregulated cerebral blood flow (CBF) leading to eventual loss of neurons in the cortex and hippocampus. These data indicate the importance of maintaining adequate pericyte numbers for proper BBB function.

Both pericytes and astrocytes are important in the preservation of BMEC TJs through the regulation of junctional proteins occludin, claudin, and ZO-1. Astrocyte end feet also contact the abluminal surfaces of BMECs and enwrap neuronal synapses, enabling simultaneous modulation neuronal activity and blood flow in response to elevations in intracellular $\mathrm{Ca}^{2+}$ levels [34, 35]. Astrocyte end feet are also highly polarized and express specialized molecules such as Kir4.1 $\mathrm{K}^{+}$channels and aquaporin 4 (AQP4), which each regulate BBB ionic concentrations, and protein transporters such as glucose transporter-1 and P-glycoprotein, the latter of which promotes the efflux of toxic substances away from brain parenchyma [36, 37]. Astrocytes may exchange signals through gap junctions forming a functional syncytium that coordinates BBB responses and communicates with neurons [38, 39]. Astrocytes critically develop and maintain BBB characteristics through the release of vascular endothelial growth factor 
(VEGF), glial cell line-derived neurotrophic factor (GDNF), basic fibroblast growth factor (bFGF), and angiopoietin (ANG)-1 [39, 40], which form TJ, promote enzymatic systems, and polarize expression of transporters [41].

The full integration of NVU responses that regulate and maintain BBB function relies on multiple signaling pathways and proteins that regulate $\mathrm{TJ}$ integrity, including calcium, protein kinase $\mathrm{A}$, protein kinase $\mathrm{C}, \mathrm{G}$ proteins, calmodulin, cAMP, and phospholipase C $[42,43]$. Heterotrimeric $\mathrm{G}$ proteins and protein kinase $\mathrm{C}$ signaling pathways, in particular, act via altering intra- and/or extracellular levels of calcium, which promotes TJ integrity [44]. Phosphorylation additionally regulates transmembrane and accessory proteins of TJs. Both serine and threonine phosphorylation of occludin, which regulates its subcellular localization, are highly correlated with the reassembly of TJs following alterations in BBB integrity [45] The PAR3PAR6-APKC pathway and the evolutionarily conserved signaling complex related to the Drosophila Stardust-Disc lost-Crumbs complex (equivalent to the mammalian Pals1-PATJ-Crumbs complex) [43] have also been implicated in regulation or modulation of TJ assembly. As PAR-complex APKC and PAR3 may be downregulated upon activation of NF-kB and, in turn, act to inhibit NF-kB-mediated signaling, these pathways may provide additional mechanisms for the alteration of $\mathrm{BBB}$ function during neuroinflammation.

In summary, the BBB has evolved numerous cellular, subcellular, and molecular mechanisms to stringently regulate the CNS access of solutes, molecules, cells, and pathogens. BBB function, however, may become dysfunctional or derailed via intrinsic and/or extrinsic effects in the setting of neuroinflammatory diseases, including those caused by autoimmune, infectious, or neurodegenerative processes.

\section{Mechanisms of BBB Disruption During Pathological Conditions}

During CNS disease, the NVU may undergo cytoarchitectural modulations that promote BBB permeability without significant alterations in structural integrity. TJs and their associated proteins are dynamically regulated and able to undergo alterations in transcription, translation, and posttranslational modifications, subcellular localization, and protein-protein interactions in normal and diseased states. Thus, acute and subtle changes in BBB permeability with accompanying mild elevations in CSF protein levels may occur without severe CNS symptoms. Prolonged alterations in NVU structure and function, however, can lead to complete TJ disruption leading to brain edema and neural cell damage and irreversible in brain injury. Here, we will discuss the role of primary or secondary BBB dysfunction in the etiology, progression, and repair of neuroinflammatory diseases. 


\section{BBB Disruption During CNS Autoimmunity}

Failure of BBB function is a critical event during the development and progression of autoimmune diseases of the CNS, including neuromyelitis optica spectrum disorders (NMOSD) and multiple sclerosis (MS). NMOSD are rare, relapsing immunemediated CNS disorders characterized by inflammation and demyelination of the optic nerves and spinal cord with evidence of BBB dysfunction in up to $70 \%$ of cases and two-thirds of patients exhibiting elevations in serum anti-AQP4 autoimmune IgG antibodies (classified as NMO patients) (reviewed in [46]). While patient serum levels of anti-AQP4 IgG are not a predictive biomarker for overall disease course [47], they are positively correlated with the extent of spinal lesions; BBB permeability, as assessed via albumin index; levels of CSF myelin basic protein concentration; and serum C3 [48]. Anti-AQP4 IgG contribute to pathogenesis via effects at astrocyte end feet within the NVU, which express AQP4, and bind to the abluminal surfaces of microvessels in NMO patients, in conjunction with lesions containing complement proteins, infiltrating neutrophils and eosinophils, and loss of AQP4 [49]. Human data are consistent with a significant role for anti-AQP4 IgG in the pathogenesis of NMO, which is further supported by the clinical efficacy of plasma exchange and B cell depletion [50]. In animal studies, targeted deletion of AQP4 or administration of anti-AQP4 IgG-positive sera plus complement from NMO patients leads to loss of BBB integrity and impaired water homeostasis within astrocyte end feet [51-53]. Similarly, using an in vitro human BBB model administration of human anti-AQP4 IgG and complement increased the migration of granulocytes across BMECs and led to astrocyte injury and decreased transendothelial electrical resistance (TEER) [54]. While the mechanism of anti-AQP4 IgG entry at the $\mathrm{BBB}$, including access to astrocyte end feet, is unclear, endothelium-specific antibodies, VEGF, and matrix metalloproteinase (MMP)-9 are all elevated in NMO $[52,55]$. Activation of BMECs via endothelium-specific antibodies may lead to concomitant upregulation of intercellular adhesion molecule (ICAM)-1 [52], promoting capture of leukocytes, and secretion of TNF and VEGF. The release of MMP-9 from infiltrating neutrophils could play a role in the degradation of the BBB ECM [55] by allowing anti-AQP4 IgG access to astrocyte AQP4. Further development of animal models of NMO could help identify therapeutic targets to prevent these effects.

The role of BBB dysfunction in the induction and progression of MS is a subject of controversy [56], mostly due to the lack of models that faithfully reproduce the diseases observed in patients. MS is a heterogeneous group of demyelinating syndromes in which patients may present with a relapsing-remitting form, characterized by periods of disease exacerbation followed by recovery and remission (RRMS). RRMS may be followed by the onset of continued progression of disease (i.e., secondary-progressive (SP)MS) or a primary progressive form in which patients continue to develop neurologic deficits without remission (PPMS) [57]. The characteristic CNS lesion observed in MS patients is a focal area of 
inflammatory-mediated demyelination surrounding postcapillary venules within white matter [58]. In severe cases of MS, patients may also exhibit demyelinating lesions within cortical gray matter, often adjacent to meninges. Defects in BBB function are observed in all lesions, with gadolinium extravasation observed using magnetic resonance imaging (MRI). However, while frank TJ disruption is not observed in MS lesions, as assessed in early studies using electron microscopy [59], the exact mechanisms of BBB impairment are unclear, as is the timing of these events as primary or secondary to the effects of immune cells.

Evidence for primary causes of BBB dysfunction include altered BMEC expression of molecules involved in the stabilization of TJs, including sphingosine 1-phosphate receptor 2 (S1P2) and claudin proteins [60, 61]. S1P2 is one of the five subtypes of G protein-coupled receptors (S1P1-5) that are targeted by S1P, a signaling, blood-borne sphingolipid that regulates angiogenesis, vascular stability, and permeability and may also be important in the pathogenesis of neurodegenerative diseases (reviewed in [62]). S1P also regulates the trafficking of T and B cells within lymphoid tissues and directly suppresses TLR-mediated immune responses from $\mathrm{T}$ cells [63]. At the BBB, S1P1 and S1P3 activation promote Rac1-mediated tightening of inter-endothelial junctions, while S1P2 leads to their disassembly via RhoA [64]. In murine models of RRMS, disassembly of BBB TJs and AJs is associated with loss of polarized expression of CXCL12 with increased capture and CNS entry of CXCR4-expressing T cells [61]. Patients with MS exhibit loss of BBB polarity within white matter lesions [65], and women with RRMS exhibit significantly higher levels of S1P2 at the NVU within hindbrain regions compared with male MS patients [61].

Loss of polarized expression of CXCL12 may also be the result of BMEC expression of the CXCL12 scavenger receptor CXCR7. Studies in animal models of MS suggest that interleukin(IL)-17-secreting CD4 and $\gamma \delta$ T cells may drive CNS autoimmunity, especially with regard to access to CNS parenchyma from perivascular spaces [66]. $\gamma \delta \mathrm{T}$ cells, which do not require antigen processing and major histocompatibility complex (MHC) presentation of peptide epitopes and instead may recognize lipid antigens, are also sources of IL-1 within the inflamed CNS [67, 68]. CXCR7 reporter mice exhibit expression of the receptor along postcapillary venules, which is increased during induction of CNS autoimmune disease, leading to loss of abluminal expression of CXCL12 and increased CNS access of myelinspecific $\mathrm{T}$ cells [31]. In vivo targeting of CXCR7 in animal studies using small molecule inhibitors maintains polarized expression of CXCL12 and limits the egress of immune cells out of perivascular spaces during induction of EAE. In vitro studies examining the regulation of CXCR7 expression on BMECs demonstrated that IL-17 and IL-1 increase the expression and activity of the receptor, respectively, consistent with in vivo studies demonstrating roles for these cytokines in driving neuropathology and the clinical effectiveness of therapies that target IL-17 or IL-1 in patients with autoimmune diseases [69-71]. Novel therapeutics targeting CXCR4 and/or CXCR7 are under development [72] and may prove beneficial for the treatment of MS. 
Although BBB disruption is clearly evident on gadolinium (gd)-MRI of MS patients, the notion that this is due to direct alterations in TJ protein expression has been controversial. Early reports examining the levels of expression of claudin-5, a major component of CNS TJs, did not reveal differences in CNS specimens from patients with and without MS [73]. More recently, claudin-11, which co-localizes with claudin-5 in CNS capillaries, was found to be significantly decreased in CNS tissue of MS patients and of mice with EAE [60]. Multiple studies, however, show leakage of serum proteins including fibrinogen, albumen, and $\mathrm{IgG}$, into CNS parenchyma within MS lesions [74, 75], which is consistent with the overall loss of BBB function. Whether this extravasation is the result of loss of gate and/or fence function, the latter of which might include alterations in BMEC intracellular endocytic pathways, remains to be determined.

\section{BBB Disruption During Neuroinfectious Diseases}

The meningeal barriers, which cover the surface of the brain and spinal cord and are comprised of the dura, arachnoid, and pia maters, effectively limit the ability of a majority of bacterial, fungal, and viral pathogens to gain access to the CNS parenchyma. Thus, only neurotropic viruses, molds, and certain parasites are able to cross the BBB and infect CNS parenchyma. Certain bacteria that gain access to the subarachnoid space within the meninges may also enter perivascular spaces of postcapillary venule, leading to BBB disruption and parenchymal infection. However, this extent of infection occurs late in the course of bacterial meningitis and is generally associated with severe and fatal outcomes. Here, we will delineate mechanisms of $\mathrm{BBB}$ disruption during neuroinfectious diseases, focusing on pathogens that infect immunocompetent hosts (Table 1).

\section{Induction of BBB Disruption and Parenchymal Invasion by Bacteria}

A variety of Gram-positive and Gram-negative bacteria display a predilection for CNS invasion, predominantly spread hematogenously within the subarachnoid space into the CSF. Most bacterial infections lead to robust inflammatory responses leading to extensive neutrophilic infiltrates throughout the meninges and, if untreated, result in vasogenic edema, disruption of the BBB, coma, and death [76]. Although bacterial infections within the CNS generally cause meningitis and are limited to the CSF compartment, host inflammatory responses and, in some cases, bacterial products may lead to BBB disruption with bacterial invasion of the CNS parenchyma. With few exceptions, most bacteria are unable to invade neural cells, leading instead to their encapsulation by glial elements and abscess formation [77]. Here, we will discuss the specific mechanisms by which bacteria interact with subarachnoid vasculature and the molecular events that may lead to parenchymal invasion. 
Table 1 Mechanisms of BBB disruption by various pathogens, including bacteria, viruses, and parasites, depicted in pink, blue, and gray, respectively

\begin{tabular}{|c|c|c|}
\hline Pathogens & Mechanisms of BBB disruption & References \\
\hline $\begin{array}{l}\text { Group B } \\
\text { Streptococcus (GBS) }\end{array}$ & $\begin{array}{l}\text { GBS activates ERK1/2/MAPK signaling pathway in } \\
\text { BMECs, leading to the induction of host transcriptional } \\
\text { repressor Snail1, which in turn suppresses the expression } \\
\text { of TJ proteins }\end{array}$ & [238] \\
\hline $\begin{array}{l}\text { Listeria } \\
\text { monocytogenes }\end{array}$ & $\begin{array}{l}\text { Bacterial proteins InlA and InlB interact with host cellular } \\
\text { receptors E-cadherin and MET, respectively, on choroid } \\
\text { plexus epithelium and brain endothelium, respectively }\end{array}$ & [86] \\
\hline Bacillus anthracis & $\begin{array}{l}\text { Reduce the expression of ZO-1 induced by bacterial } \\
\text { edema toxin (ET) } \\
\text { Bacterial toxins also reduce the expression of VE-cadherin } \\
\text { by inhibiting Rab11/Sec15-dependent endocytic recycling } \\
\text { pathway }\end{array}$ & {$[239,240]$} \\
\hline $\begin{array}{l}\text { Haemophilus } \\
\text { influenzae }\end{array}$ & $\begin{array}{l}\text { Porin, OmpP2 causes endothelial damage via binding to } \\
\text { the common carboxy-terminal domain of LR, and pili } \\
\text { interact with platelet-activating factor receptor (PAFR), } \\
\text { both expressed by BMECs }\end{array}$ & {$[95,96]$} \\
\hline $\begin{array}{l}\text { Neisseria } \\
\text { meningitidis }\end{array}$ & $\begin{array}{l}\text { Degradation of TJ proteins and ECM via the induction of } \\
\text { MMP8 } \\
\text { Delocalization of TJ proteins in BMECs induced by } \\
\text { bacterial pili }\end{array}$ & [241-243] \\
\hline WNV (Flavivirus) & $\begin{array}{l}\text { Degradation of TJ and AJ proteins mediated by virus- } \\
\text { induced elevation of MMP- } 1,-3 \text {, and- } 9\end{array}$ & {$[104,244]$} \\
\hline JEV (Flavivirus) & $\begin{array}{l}\text { Disruption of TJ complexes by virus-induced } \\
\text { inflammatory cytokines (e.g., IP-10 and TNF } \alpha \text { ) in the CNS }\end{array}$ & [109] \\
\hline TBEV (Flavivirus) & $\begin{array}{l}\text { Virus-induced cytokine/chemokine overproduction in the } \\
\text { brain }\end{array}$ & [172] \\
\hline HIV-1 (Retrovirus) & $\begin{array}{l}\text { Inducing lesion in brain ECs and activation of MMPs by } \\
\text { gp120 } \\
\text { Release of s-CD } 40 \text { L by Tat-induced platelet activation }\end{array}$ & $\begin{array}{l}{[135,136,} \\
245]\end{array}$ \\
\hline $\begin{array}{l}\mathrm{HeV} \text { and } \mathrm{NiV} \\
\text { (Henipavirus) }\end{array}$ & $\begin{array}{l}\text { Syncytium formation in brain ECs. Induction of } \\
\text { inflammatory cytokines in the brain and peripheral tissues }\end{array}$ & [129-131] \\
\hline VEEV (Alphavirus) & $\begin{array}{l}\text { Increased expression of MMP9 } \\
\text { Monocytes infiltration and release of inflammatory } \\
\text { cytokines }\end{array}$ & {$[102,105]$} \\
\hline RABV (Lyssavirus) & $\begin{array}{l}\text { Downregulation of TJs mediated by IFN- } \gamma \text { from infiltrating } \\
\text { CD4 T cells }\end{array}$ & [182] \\
\hline MHV3 (Coronavirus) & $\begin{array}{l}\text { Reduced expression of TJ and AJ proteins due to impaired } \\
\text { production of IFN- } \beta \text { by infected BMECs }\end{array}$ & [111] \\
\hline LCMV (Arenavirus) & $\begin{array}{l}\text { CTL-mediated recruitment of neutrophils and monocytes } \\
\text { into the CNS leads to vascular damage }\end{array}$ & [181] \\
\hline $\begin{array}{l}\text { Influenza A virus } \\
\text { (Orthomyxovirus) }\end{array}$ & $\begin{array}{l}\text { Disruption of tight junction protein ZO-1, likely by } \\
\text { virus-induced inflammatory cytokines }\end{array}$ & {$[246,247]$} \\
\hline TMEV (Cardiovirus) & Degradation of TJs by perforin secreted from CD8 T cells & [184] \\
\hline HSV-1 (Simplexvirus) & Virus-induced upregulation of MMP9 & [248] \\
\hline
\end{tabular}


Table 1 (continued)

\begin{tabular}{l|l|l}
\hline Pathogens & Mechanisms of BBB disruption & References \\
\hline P. falciparum (HCM) & $\begin{array}{l}\text { Parasite-induced structural change in the membrane of } \\
\text { iRBC makes them adherent to vascular endothelium, } \\
\text { resulting in apoptosis and disruption of TJ proteins in } \\
\text { BMECs }\end{array}$ & {$[193]$} \\
\hline $\begin{array}{l}\text { P. berghei ANKA } \\
\text { (ECM) }\end{array}$ & $\begin{array}{l}\text { Platelets deposition and leukocyte arrest on brain vascular } \\
\text { endothelium Degradation of TJs and extracellular matrix } \\
\text { by CD8 T cells }\end{array}$ & {$[204-206]$} \\
\hline Toxoplasma gondii & $\begin{array}{l}\text { Upregulation of CAMs and inflammatory cytokines in the } \\
\text { CNS. Sustain and intense interaction/adherence of } \\
\text { leukocytes with brain endothelium Production of nitric } \\
\text { oxide and MMPs in the CNS }\end{array}$ & {$[35-38]$} \\
\hline Trypanosoma brucei & $\begin{array}{l}\text { Enhanced production of pro-inflammatory cytokines by } \\
\text { activated microglial and astrocytes. T cell-mediated } \\
\text { activation of MMPs }\end{array}$ & {$[219]$} \\
\hline Acanthamoeba & $\begin{array}{l}\text { Degradation of TJ proteins. Induction of cell cycle arrest } \\
\text { and apoptosis in BMECs through activation of PI3K }\end{array}$ & {$[228]$} \\
\hline
\end{tabular}

\section{Streptococcus pneumoniae (aka Pneumococcus)}

S. pneumoniae are Gram-positive, facultative anaerobic bacteria that reside in the respiratory tract. There are over 90 serotypes of $S$. pneumoniae that differ in virulence and susceptibility to antimicrobials. Pneumococcal infections generally originate in the nasal cavities but, in young children and the elderly, may become invasive, with hematogenous spread to multiple organs including the CNS. Within the subarachnoid space, S. pneumoniae may adhere to fenestrated endothelium via a number of interactions between bacterial and host proteins. Thus, the major adhesion protein of $S$. pneumoniae pilus-1, $\operatorname{RrgA}$, binds both polymeric immunoglobulin receptor (pIgR) and platelet-associated cell adhesion molecule (PECAM)-1 on endothelial cells, while the bacterial choline-binding protein (PspC) binds only pIgR [78]. These interactions trigger Toll-like receptor-mediated expression of inflammatory mediators by meningeal endothelial cells including interleukins (IL)1, -6, -10, tumor necrosis factors (TNF), and cytokine-induced neutrophil chemoattractant (CINC)-1 [79, 80]. The recruitment of neutrophils and lymphocytes heralds the onset of meningitis symptoms, including fever, photophobia, and meningismus [81]. Untreated, inflammatory infiltrates may gain access to the CNS parenchyma via migration along venules from the meningeal compartment. Neutrophils and macrophages secrete barrier destabilizing cytokines, IL-1, and TNF, which activate RhoA within BBB endothelial cells, which disrupts TJs [15]. In severe infections, $S$. pneumoniae may also gain access to the brain parenchyma, as animal studies demonstrate that pneumococcal pneumolysin may damage endothelial cell membranes or TJs [82]. 


\section{Listeria monocytogenes}

Listeria monocytogenes is a facultative intracellular bacterium that is tenfold more effective at invading the CNS other than neuroinvasive Gram-positive bacteria [83]. L. monocytogenes spreads hematogenously from the gastrointestinal tract after the consumption of contaminated food, gaining access to the CNS parenchyma through a variety of routes including invasion of meningeal endothelium, transportation across the BBB within infected monocyte, or retrograde migration along cranial nerve axons $[84,85]$. Bacterial proteins, including internalins (InlA and InlB), interact with host cellular receptors E-cadherin and mesenchymal-epithelial transition (MET), respectively, and are expressed by choroid plexus epithelium and brain endothelium, respectively [86]. Listeriolysin O (LLO), a pore forming toxin, activates NF-kB within brain endothelial cells in vitro, leading to increased expression of P- and E-selectin, ICAM-1 and VCAM-1, as well as IL-6, -8, and CCL2, which may promote the adhesion and recruitment of neutrophils and monocytes [87]. Invasion and infection of brain endothelial cells with the ensuing activation of glial cells and recruitment of leukocytes in patients with severe CNS L. monocytogenes infections may lead to abscess formation or cerebritis [88].

\section{Bacillus anthracis}

Bacillus anthracis, a spore-forming Gram-positive bacterium, causes the disease anthrax, which has three clinical forms: cutaneous, inhalational, and gastrointestinal [89]. Untreated, anthrax disseminates hematogenously to the CNS, causing fatal hemorrhagic meningitis. Anthrax toxins, such as InhA and BsIA, induce destruction of brain endothelial cell TJs, leading to increased BBB permeability and hemorrhage [90, 91]. BsIA has also been demonstrated to act as an adherence factor for all endothelial cells and to be required for CNS infection [92]. Finally, the anthrax toxin $\mathrm{pXO1}$ downregulates innate immune responses, allowing dissemination of the pathogen throughout the CNS [93].

\section{Haemophilus influenzae}

Haemophilus influenzae is a Gram-negative bacterium that was a leading cause of childhood meningitis until its near eradication through the introduction of a the highly effective conjugate $\mathrm{HiB}$ vaccine [94]. In vitro studies have implicated $H$. influenzae porin, OmpP2, in endothelial damage via binding to the common carboxyterminal domain of LR, and $H$. influenzae pili have also been shown to interact with platelet-activating factor receptor (PAFR), which are both expressed by BMECs [95, 96]. In vivo studies have shown that targeting leukocyte CD11/CD18 integrins in conjunction with systemic treatment with corticosteroids reduces life-threatening CNS inflammation and prevents TJ disruption [97], the latter of which is now standard of care in the treatment of patients with H. influenzae meningitis [98]. 


\section{Neisseria meningitidis}

Neisseria meningitidis, a Gram-negative bacterium that may colonize the oropharynx and genital tract, causes fulminant meningococcemia and meningococcal meningitis, which often occur together [99]. N. meningitidis adheres to host endothelial cells via pili surface proteins Opa and Opc followed by bacterial adhesin PilQ interaction with the common carboxy-terminal domain of LR [96]. Additional determinants of host cell binding include complex protein ACP and the autotransporter meningococcal serine protease (Msp) A [100, 101].

In summary, while bacterial invasion of the CNS is primarily limited to the meningeal compartment, numerous species exhibit pili surface proteins that are able to interact with BMECs via binding to $\mathrm{pIgR}$ and/or LR, which lead to endothelial cell activation, with upregulation of PAFr, CD31, and/or intercellular adhesion molecules [95]. PAFr activation leads to dilation of vessels, aggregation of platelets, and increased $\mathrm{BBB}$ permeability, which are all terminal events during bacterial meningitis.

\section{Effects of Viruses on BBB Structure and Function}

Many neurotropic viruses with barrier disrupting properties (e.g., Japanese encephalitis virus (JEV), West Nile virus (WNV), Venezuelan equine encephalitis virus (VEEV)) enter the CNS in the absence of BBB opening, suggesting that barrier disruption results from the local virus replication in the CNS [102-106]. Viruses can compromise the integrity of BBB by either infecting or inducing cellular damage to the NVU or by eliciting innate and adaptive immune responses leading to neuroinflammation. Thus, a combination of host and virus-related factors contributes to $\mathrm{BBB}$ opening during neurotropic viral infection.

\section{Virus Factors that Impact BBB}

Infection of mice with mouse adenovirus type-1 (MAV-1) induces BBB disruption in the absence of inflammation, suggesting that the barrier loss is primarily caused by viral infection rather than inflammatory responses [107]. MAV-1 infects brain vascular endothelium in vivo [108] and dampens expression of TJ proteins in vitro [107]. Indeed, reduced expression of TJ and AJ proteins is a characteristic feature of BBB disruption by neurotropic viruses such as JEV, WNV, and human immunodeficiency virus type 1 (HIV-1) in vivo [104, 109, 110]. Viruses accomplish this either by downregulating transcription levels of TJ mRNA or promoting protein degradation [104, 111].

Disruption of TJ complexes is often associated with enhanced generation of reactive oxygen species (ROS). Viral infection in target cells can induce mitochondrial damage or NADPH oxidase activation, resulting in robust ROS generation $[112,113]$. While low levels of ROS are required for normal cell function, unchecked 
level of these reactive intermediates can exert detrimental effects. Indeed, ROS can target virtually all biological molecules, including lipid, protein, and nucleic acid, resulting in the release of various cytokines and proteases that damage vasculature. Cellular component of NVU can be a source and target of ROS. While brain endothelial cells are highly susceptible to oxidative stress, astrocytes are less prone to such damages. However, exposure to viral proteins (e.g., HIV-1 Nef) augments astrocyte sensitivity to redox insults [114]. Activation of metalloproteinases (MMPs) is one of the mechanisms by which ROS dysregulate TJ complexes [115-117]. Elevated levels of MMPs have been reported in brain tissue of mice infected with neurotropic viruses such as WNV, JEV, and VEEV $[104,105,118]$ and in cerebrospinal fluid (CSF) of human patients infected with WNV [118]. Infected microglia and astrocytes robustly elevate the expression of MMP-2 and -9 in vitro and in vivo $[119,120]$. MMPs are known to disrupt the BBB integrity by cleaving TJ proteins, AJ proteins, and the extracellular matrix (ECM) [115]. Activity of these MMPs is controlled by regulating gene expression, activation, and inhibition mediated by endogenous tissue inhibitors of MMPs (TIMPs) [121]. Nonetheless, viral infection (e.g., HIV-1) can perturb the fine balance between MMPs and TIMPs, resulting in enhanced MMP levels and BBB leakage [122]. Consistently, pharmacological blockage or genetic ablation of MMPs is reported to protect BBB integrity upon viral infection in murine models $[118,123]$.

Additionally, ROS trigger the small GTPase RhoA, PI3 kinase, and protein kinase $\mathrm{B}$ (PKB/Akt) signaling pathways. This results in the reorganization of the actin cytoskeleton, altered localization of $\mathrm{TJ}$ proteins, and consequently increased BBB permeability $[124,125]$. Furthermore, ROS can cause barrier dysfunction by activating inflammasome via signaling pathways involving mitogen-activated protein kinases (MAPK) and extracellular signal-regulated protein kinases 1 and 2 (ERK1/2) [126].

Viruses can also infect brain endothelial cells and induce syncytium resulting in vascular damage and hemorrhage [127, 128]. For instance, Nipah and Hendra viruses (NiV and $\mathrm{HeV}$, respectively) invade the CNS by infecting brain endothelial cells. Virus infection induces syncytium in brain endothelium resulting in extensive vascular damage associated with influx of inflammatory cells [129-131]. Additionally, neurotropic viruses induce apoptosis in brain endothelial cells causing BBB dysfunction in vitro [132]. Secretory viral proteins also trigger barrier permeability. For instance, HIV-1 Tat protein is actively released from the infected cells and crosses the cellular membrane [133]. Intravenous injection of mice with HIV-1 Tat reduces the expression of TJ proteins in brain vasculature, partly by upregulating cyclooxygenase-2 expression [134]. Additionally, HIV-1 Tat enhances serum levels of soluble CD40L (sCD40L) by activating platelets $[135,136]$, a phenomenon also observed in HIV-infected patients [137, 138]. sCD40L alters barrier permeability by increasing the expression of cell adhesion molecules on brain endothelial cells in a JNK-dependent manner [139]. This culminates in enhanced leukocyte adhesion to brain endothelium leading to BBB dysfunction [135].

In summary, evidence indicates that neurotropic viruses can directly induce BBB permeability by disrupting TJs and AJs between brain endothelial cells. This is 
mainly achieved by inducing ROS generation in the CNS, which in turn activates several tyrosine kinases, MMPs, and small GTPase RhoA. The cumulative effect of these activities leads to the loss of BBB function.

Innate Immune Responses to Viruses that Impact BBB Function

Microbes possess pathogen-associated molecular patterns (PAMPs) that are recognized by pattern recognition receptors (PRRs), such as Toll-like receptors (TLRs), retinoic acid-inducible gene 1 (RIG-I)-like receptors (RLRs), nucleotide oligomerization domain-like receptors (NLRs), and cytosolic DNA sensors. These PRRs are expressed by various cell types in the CNS (reviewed in [140]). Viruses contain single- or double-stranded RNA molecules (dsRNS and ssRNA, respectively), present either in the viral genome or generated during virus replication. Recognition of viral PAMPs by TLR3 (dsRNA) or TLR-7 (ssRNA) triggers signaling pathway related to NF-kB, resulting in the production of pro-inflammatory cytokines and type I interferons (IFNs). Similarly, RLRs, which include RIG-I and melanoma differentiation factor (MDA)-5, are activated by dsRNA and ssRNA sequences containing 5'-triphosphate [141]. RLR activation stimulates mitochondrial antiviral-signaling protein (MAVS), which in turn elicits the expression of inflammatory cytokines via induction of the NF- $\mathrm{kB}$ signaling pathway. While PRRinduced expression of type I IFNs restricts virus replication in the CNS [142, 143], enhanced production of pro-inflammatory cytokines and chemokines can lead to neuroinflammation. Studies have shown that TLR3 signaling contributes to both enhancement and protection of CNS inflammation during WNV infection in murine models [144, 145]. Similarly, TLR3 signaling has been associated with neuropathogenesis of rabies virus (RABV) in mice [146] while limiting infection of herpes simplex virus (HSV)-2 in the CNS through the activation of IFNAR signaling in astrocytes [142].

The NLR family is involved in the maturation of pro-inflammatory cytokines, produced by other PRRs (e.g., TLRs and RLRs) in response to viral infection. Viral sensing by NLRs triggers the assembly and activation of inflammasome complex, resulting in the maturation and release of interleukin-1 $\beta$ (IL-1 $\beta$ ) and IL-18 from infected cells (reviewed in [140]). Seemingly, IL-1 $\beta$ acts in synergy with type I IFNs to suppress virus replication in cortical neurons, thus providing protection against lethal WNV infection in mice [147]. In contrast, enhanced production of IL-1 $\beta$ is linked to neuropathology associated with JEV infection in murine models [148]. IL-1 $\beta$ also abrogates the protective effect of astrocytes on BBB integrity by suppressing astrocytic expression of sonic hedgehog ( $\mathrm{SHH})$, a protein that upregulates the expression of TJs in BMECs [149]. Additionally, IL-1 $\beta$ and IL-18 activate microglia and astrocytes to generate more inflammatory molecules potentiating inflammation. Activation of microglia is often reported during encephalitic viral infection [104, 150-153], which is regulated by IFNAR signaling in astrocytes and neurons [154]. While microglia play a crucial role in viral clearance in the CNS [154-156], uncontrolled gliosis can disrupt BBB integrity through induction of pro-inflammatory 
cytokines and matrix metalloproteases [153]. Similarly, astrocytes mount a strong innate immune response upon recognition of viral PAMPs via RLR and TLR signaling pathways. In fact, astrocytes are the main producers of type I IFNs during infection with several distinct neurotropic viruses, including La Crosse virus, rabies virus (RABV), vesicular stomatitis virus (VSV), and Theiler's murine encephalitis virus (TMEV) $[157,158]$. Deletion of IFNAR signaling specifically in astrocytes results in severe encephalomyelitis and mortality during otherwise nonlethal mouse hepatitis virus (MHV) [159]. Nonetheless, activated astrocytes can release excess amount of IP-10 during encephalitic viral infection [109]. IP-10 enhances the expression of tumor necrosis factor alpha $(\mathrm{TNF} \alpha)$ in a JNK-dependent manner, leading to barrier disruption [109]. Consistently, injection of mice with neutralizing antibodies against IP-10 [109] or TNF- $\alpha$ ameliorated the decrease in TJ proteins and improved BBB integrity during JEV infection [160].

Alternatively, viral-induced inflammasome activation triggers pyroptosis, a highly inflammatory form of programmed cell death [161]. Although pyroptosis plays a crucial role in controlling virus spread [162], it can cause neuronal necrosis and gliosis [163], features associated with BBB disruption. In the CNS, inflammasome activity is regulated by mechanisms involving osteopontin (OPN) and prostaglandin D2 (PGD2), upon viral infection [164, 165]. OPN inhibits the caspase-1-dependent inflammasome activation by reducing the expression of inflammasome components in the brain [165]. However, PGD2 can exert both pro- and anti-inflammatory effects depending on the receptor involved. Engagement of D-prostanoid receptor 1(DP1) on microglia by PGD2 upregulates PYDC3 (an inflammasome inhibitor), which protects against IL-1 $\beta$-mediated neuroinflammation [164]. Deficiency in DP1 also correlates with reduced expression of IFN-I and -III, augmenting viral titer in the brain. Interestingly, upon viral infections, IFNAR signaling in BMECs reduces expression of IL-1 $\beta$ [15], likely via inhibition of inflammasome activity [166]. Additionally, type I IFNs act in synergy with MerTK (a member of TAM receptor tyrosine kinases) to activate Rac-1, which in turn improves TJ integrity [167].

Taken altogether, these studies suggest that innate immunity plays a central role in restricting viral replication in the CNS. This has the potential to be protective or detrimental, depending on the virus and magnitude of host immune response. The protective effect is mainly attributed to IFNAR signaling in CNS residential cells that not only limits local virus replication but also restricts additional viral entry or leukocyte infiltration by retaining BBB integrity.

\section{Adaptive Immune Responses to Viruses that Impact BBB Function}

Leukocyte migration across the BBB requires expression of ICAM-1 and VCAM-1 on brain endothelial cells (ECs). As mentioned above, under normal conditions, these molecules are expressed minimally on brain ECs to restrict immune cell interaction and extravasation into the CNS. However, elevated expression of ICAM-1 and VCAM-1 has been frequently observed in infection with several neurotropic 
viruses [168-172]. Altered expression of these adhesion molecules mainly results from the activation of NF- $\mathrm{KB}$ by ROS or ERK signaling pathway. For instance, HIV-1 Tat protein induces NADPH oxidase in astrocytes, which results in the upregulation of CAMs expression via NF-kB signaling [173, 174]. Similarly, JEV infection augments ICAM-1 expression on brain endothelial cells through activation of ERK signaling pathway [171]. Interestingly, expression of CAMs on brain endothelium is downregulated by IFNAR signaling in astrocytes, which promotes BBB integrity during encephalitic viral infection [170]. Additionally, IFNAR signaling in astrocytes influences the composition of inflammatory cells recruited to the CNS upon viral infection [159].

Although immune cell infiltration is crucial for viral clearance in the CNS [147, $175,176]$, it can cause BBB disruption and neuronal damage by potentiating neuroinflammation [104]. Studies have shown that immune cell infiltration precedes BBB disruption in mice infected with VEEV and tick-borne encephalitic virus (TBEV) $[102,172]$. This is associated with increased expression of RANTES, CCL2, IP-10, ICAM-1, TNF- $\alpha$, IL-6, and IL- $1 \beta$ in brain tissues [172]. Similarly, enhanced levels of CCL2 and RANTES have been reported in serum samples of TBE-infected human patients [177]. Activated monocytes produce CCL2 in response to viral infections, which promotes barrier permeability via alteration in the actin cytoskeleton and localization of TJ proteins [178, 179]. Additionally, infiltrating neutrophils and monocytes produce high levels of MMP8, which promotes myelomonocytic cell extravasation and vascular leakage upon infection with lymphocytic choriomeningitis virus (LCMV) [180]. Consistently, depletion of both monocytes and neutrophils in LCMV-infected mice promotes BBB integrity and prolonged survival [181]. Notably, individual depletion of either cell type does not protect against vascular permeability.

As with monocytes, infiltrating lymphocytes can also induce BBB disruption by secreting inflammatory cytokines. Infected neurons produce CXCL10, which is a chemoattractant for CD4 and CD8 T cells [176]. Upon infection with rabies virus, CD4 T cells infiltrate into the CNS and differentiate into Th1 and Th17 that produce IFN- $\gamma$ and IL-17, respectively $[182,183]$. While IFN- $\gamma$ reduces the expression of TJ proteins (i.e., occludin, claudin-5, and ZO-1), elevated levels of IL-17 disrupt TJ complexes in infected mice [182]. Consistently, blockage of IFN- $\gamma$ ameliorated BBB integrity in vivo, presumably by restoring expression of TJ proteins in brain endothelial cells [182]. Administration of IFN- $\gamma$-neutralizing antibody also alleviated BBB disruption in JEV-infected mice [103]. CD8 T cells are also involved in vascular leakage during viral infection. They promote BBB disruption during infection with TMEV (Theiler's murine encephalomyelitis virus), by releasing perforin that disrupts TJ proteins [184]. Additionally, it has been suggested that interaction of CD8 T cells with neurons upregulates VEGF, which in turn promotes barrier dysfunction by dysregulating TJ complexes [184, 185]. Another mechanism by which cytotoxic T cells (CTLs) can cause vascular leakage involves degradation of the basal membrane via secretion of granzyme B. This allows CTLs to extravagate across brain vasculatures [186]. Upon extravasation, CD8 T cells release several 
chemoattractants (e.g., CCL2, CCL3, and CCL4), which recruit monocytes and neutrophils to the CNS, thus indirectly leading to the loss of $\mathrm{BBB}$ function during viral infection [181].

Notably, physical interaction of infiltrating leukocytes with ICAM-1 on brain endothelium per se can promote vascular permeability by triggering generation of ROS in a NADPH oxidase and Rac-1-dependent manner [187-189]. Enhanced generation of ROS activates downstream tyrosine kinases (e.g., c-Src and PYK2), resulting in phosphorylation of VE-cadherin. This phosphorylation dissociates interaction of VE-cadherin with the actin cytoskeleton resulting in the disruption of adherent junctions. Likewise, TNF $\alpha$ and VEGF that are generated during viral infection $[109,120]$ trigger Rac-1-mediated ROS generation. ROS in turn promotes phosphorylation and internalization of VE-cadherin, leading to barrier dysfunction [188, 190, 191].

Collectively, the above studies suggest that upon viral infection, CNS residential cells release inflammatory cytokines/chemokines, which activate brain endothelium allowing immune cell infiltration. Infiltrating leukocytes provide microglia with costimulatory signals to eliminate infected cells. Additionally, cytotoxic T cells can directly kill infected cells contributing to viral clearance. Nonetheless, an excessive immune cell infiltration imposes severe structural damages to the cells of NVU, leading to barrier dysfunction.

\section{Effects of Parasites on BBB Structure and Function}

As with other pathogens, neurotropic parasites have evolved several strategies to disrupt the BBB promoting their entry into the brain. These include infection and lysis of brain ECs (e.g., Toxoplasma gondii), secretion of proteases and toxins (e.g., trypanosoma and acanthamoeba), and induction of inflammatory cytokines or matrix metalloproteinases [192].

\section{Cerebral Malaria and BBB Function}

Plasmodium falciparum, the causative agent of human cerebral malaria (HCM), is associated with disruption of BBB and severe vasculopathy. Infection of red blood cells (RBCs) by P. falciparum induces structural changes in their membrane that make them adhesive to other cell types. This results in the formation of mircoaggregates that can obstruct blood flow, leading to hypoxia, hypertension, and alteration of metabolites in the CNS [192]. Additionally, infected RBC (iRBC) can directly interact with brain vascular endothelium and promote BBB dysfunction. Indeed, adhesion and sequestration of $i R B C s$ in brain vasculature are linked to the loss of BBB function in humans [193, 194]. In vitro studies also have shown that adherence of iRBCs to brain endothelium triggers barrier permeability via induction of apoptosis and disruption of TJ proteins (e.g., ZO-1) [195-197]. In mouse models 
of experimental cerebral malaria (ECM), BBB dysfunction correlates with platelet deposition and leukocyte arrest on the endothelium of postcapillary venules [198, 199]. Activated platelets augment BBB permeability by potentiating vascular damage induced by $\mathrm{iRBC}$ and impairing vascular repair. Similarly, leukocyte arrest, along with increased production of vasoconstrictive factors, impairs venous efflux from the CNS. This results in enhanced intracranial hypertension, vascular leakage, and hemorrhages [200, 201]. Among leukocytes, antigen-specific CD8 T cells and ICAM- $1^{+}$macrophages are particularly involved in the development of ECM [198]. Plasmodium species upregulate the expression of ICAM-1, VCAM-1, P-, and E-selectins both in human and mice, thus promoting immune cell extravasation into the CNS [202, 203]. Antigen-specific CD8 T cells trigger BBB permeability by secreting granzyme $\mathrm{B}$ and perforin that target $\mathrm{TJ}$ proteins and induce apoptosis in brain endothelial cells [204-206]. Nonetheless, endothelial cell death is not correlated with barrier dysfunction or development of ECM in other studies [198, 199]. Instead, BBB disruption is related to increased paracellular or transcellular transport, mediated by the interaction of leukocytes with postcapillary venules [199]. Furthermore, antigen-specific CD8 T cells activate brain endothelial cells by releasing IFN-y [207], which upregulates the expression of adhesion and antigenpresenting molecules selectively on cerebrovascular ECs but not peripheral ECs $[207,208]$. Consistently, deficiency in IFN- $\gamma$ or depletion of CD8 T cells results in complete protection against ECM by preventing barrier permeability and vascular hemorrhage [207, 209]. Likewise, co-infection with chikungunya virus (CHIKV) protects mice from ECM mortality by preventing pathogenic CD8 $\mathrm{T}$ cells from migration into the CNS [210].

\section{Toxoplasmosis}

Toxoplasmosis is one of the most common parasitic diseases that is caused by Toxoplasma gondii. In healthy individuals, infection is either mild or asymptomatic; however, it can cause life-threatening CNS complications in developing fetus or immunocompromised patient [211]. Upon infection, T. gondii can enter CNS via Trojan horse as well as direct infection of brain endothelial cells [192, 212]. During acute phase, the parasite induces an exacerbated inflammatory response, which then subsides during the chronic phase. Inflammatory response upregulates expression of VCAM-1 on brain endothelium to promote migration of CD4 T cells into the CNS, which is required for controlling parasite replication [213]. Nonetheless, sustained and intense leukocyte-endothelium interaction in postcapillary venules leads to the formation of plugging, which can interfere with blood flow and cause cerebral hypoperfusion [214, 215]. Additionally, T. gondii can infect, lyse, and induce structural and functional defects in brain endothelial cells $[192,215]$. Furthermore, elevated levels of MMPs, inflammatory cytokines, and nitric oxide are reported during parasite infection, features associated with BBB disruption $[216,217]$. 


\section{Trypanosomiasis}

Human African trypanosomiasis (HAT), also known as "sleeping sickness," is caused by Trypanosoma brucei. HAT is divided into two clinical stages: during the first stage, parasite replicates in the blood and lymphatic system. This is followed by a second stage when the parasite enters and establishes infection in the CNS, which can cause meningoencephalitis [218]. T. brucei initially enters the CNS through choroid plexus and circumventricular organs, likely by secreting a protease that degrades the basal lamina [219, 220]. During the early phase of CNS infection, production of IL-6 and IL-10 protects against neuroinflammation [221]. However, later in disease, activated microglia and astrocytes produce high levels of inflammatory cytokines (e.g., IL-1 $\beta$, CXCL-8, CCL-2, and TNF- $\alpha$ ), which can lead to severe neuropathology [222]. These inflammatory cytokines upregulate the expression of cells adhesion molecules (i.e., ICAM-1, VCAM-1, and E-selectin) on brain endothelial cells, which promotes leukocyte migration into the CNS. Infiltrating lymphocytes are particularly involved in the entry of parasite across BBB. They secret IFN- $\gamma$, which in turn activates MMP9, a protease that degrades astrocytic basement membrane allowing paracellular entry of parasite into the CNS [219]. Consistently, enhanced expression of MMPs is reported during Trypanosoma infection [223, 224]. Additionally, IFN- $\gamma$ augments the expression of CXCL-10 by astrocytes, which recruits more lymphocytes into the CNS [225]. Furthermore, T. brucei releases cysteine proteases that trigger protease-activated receptors (PARs) on BMECs, thereby promoting BBB dysfunction through enhancement of intracellular calcium level [226]. Interestingly, production of nitric oxide by perivascular macrophages restricts the entry of both parasites and activated T cells into the CNS by preserving BBB integrity [224].

\section{Amoebic Encephalitis and BBB Effects}

Acanthamoeba castellanii is a fatal infection of immunocompromised individuals and is associated with BBB dysfunction and has been shown to cause granulomatous encephalitis in immunocompromised patients. It invades the CNS through hematogenous pathway following disruption of the BBB [227]. A. castellanii interacts with BMECs through a mannose-binding protein that is expressed on the surface of its trophozoites. These interactions trigger degradation of TJ proteins (e.g., occludin and ZO-1) in a Rho kinase-dependent manner [228]. Additionally, parasite interaction can induce cell cycle arrest and apoptosis through activation of phosphatidylinositol 3 kinases (PI3K) and inhibition of proteins that are involved in cell cycle progression [229, 230]. Similarly, cell cycle arrest and apoptosis of brain endothelial cells have been reported for Balamuthia mandrillaris, another parasite that is known to cause fatal amoebic meningoencephalitis [231]. Notably, host immune response plays a major role in the disruption of BBB during infection with A. castellanii and Naegleria fowleri [227, 232]. Since these amoebae are relatively 
large in size, they elicit an amplified immune response that not only compromises the BBB integrity but also causes neuronal damage [232].

Neurotropic parasites (e.g., Trypanosoma, Acanthamoeba, and Balamuthia species) are also known to produce and release a variety of proteases (e.g., cysteine and serine proteases and metalloproteinases) that target TJ proteins and the basal membrane of the BBB, leading to barrier dysfunction [233-236]. Proteases interact with protease-activated receptors on BMEC and stimulate calcium release from intracellular stores by activating phospholipase C (PLC) [226]. Increased calcium levels result in calmodulin activation of myosin light chain, which in turn augments intracellular contraction, leading to disruption of TJs between brain ECs [237].

\section{Future Perspectives}

Since the initial demonstration and appreciation of the specialized nature of the CNS microvasculature, researchers have learned that it is less an impermeable barrier and more a dynamic interface that senses and responds to the periphery. These responses are generally neuroprotective, such as the IFNAR-mediated increase in $\mathrm{TJ}$ integrity during viral invasion or the stringent regulation of $\mathrm{T}$ cell access that can promote efficient clearance of pathogens, such as $T$. gondii, without excessive immunopathology. Pathogens have evolved various mechanisms to exploit cellular and molecular processes that control the CNS access, such as the reduction in expression of ZO-1 induced by the B. anthracis edema toxin (ET). Host responses, in turn, regulate immune cell infiltration into the CNS via antigen-specific events that allow leukocyte localization, interactions, and egress from perivascular spaces such that inflammation is efficiently directed at pathogen elimination. The interaction of immune cells with BMECs destabilizes junctional molecules via cytokinemediated signaling events that alter the structural properties of these cells. Thus, the most severe outcomes in the context of neuroinfectious diseases that enter the CNS via the BBB arise from host inflammatory responses rather than due to direct effects of pathogens themselves. This is particularly evident in the context of autoimmune diseases of the CNS where leukocytes gain inappropriate access to the CNS and cause extensive damage without acute infection.

While we continue to improve our understanding of these processes, the challenge will be to better identify mechanisms that promote efficiency in immunemediated pathogen clearance while enhancing the CNS' own neuroprotective mechanisms. The use of animal models of neuroinfectious diseases that focus on various aspects of these processes in conjunction with the development of methods to isolate cellular participants, such as RiboTag or single cell RNA sequencing, in conjunction with cell-specific gene deletion strategies will permit cell-type-specific evaluation of mRNA expression and protein functions during the course of in vivo pathogen invasion, infection, and clearance. The advent of techniques in which human-induced pluripotent stem cells (hiPSCs) can be differentiated into all members of the NVU which are then incorporated into three-dimensional, fluid-based 
models of the human BBB also holds promise for identifying molecular players in this process and validating results in human systems. Future studies are likely to uncover novel neuroimmune pathways that may be safely targeted to prevent or treat infections of the CNS while also providing strategies for manipulating BBB function for the purposes of drug delivery or immunotherapies for noninfectious neurologic diseases.

\section{References}

1. Battelli F, Stern L. Die Oxydationsfermente. Ergeb Physiol. 1912;12:96-268.

2. Barker RA, Widner H. Immune problems in central nervous system cell therapy. NeuroRx. 2004;1(4):472-81. https://doi.org/10.1602/neurorx.1.4.472. PubMed PMID: 15717048; PubMed Central PMCID: PMCPMC534953.

3. Medawar PB. Immunity to homologous grafted skin; the fate of skin homografts transplanted to the brain, to subcutaneous tissue, and to the anterior chamber of the eye. Br J Exp Pathol. 1948;29(1):58-69. PubMed PMID: 18865105; PubMed Central PMCID: PMCPMC2073079.

4. Wilson EH, Weninger W, Hunter CA. Trafficking of immune cells in the central nervous system. J Clin Invest. 2010;120(5):1368-79. https://doi.org/10.1172/JCI41911. PubMed PMID: 20440079; PubMed Central PMCID: PMCPMC2860945.

5. Liebner S, Dijkhuizen RM, Reiss Y, Plate KH, Agalliu D, Constantin G. Functional morphology of the blood-brain barrier in health and disease. Acta Neuropathol. 2018;135(3):311-36. https://doi.org/10.1007/s00401-018-1815-1. PubMed PMID: 29411111.

6. Gottschall PE, Howell MD. ADAMTS expression and function in central nervous system injury and disorders. Matrix Biol. 2015;44-46:70-6. https://doi.org/10.1016/j.matbio.2015.01.014. PubMed PMID: 25622912; PubMed Central PMCID: PMCPMC5068130.

7. Laguri C, Arenzana-Seisdedos F, Lortat-Jacob H. Relationships between glycosaminoglycan and receptor binding sites in chemokines-the CXCL12 example. Carbohydr Res. 2008;343(12):2018-23. https://doi.org/10.1016/j.carres.2008.01.047. PubMed PMID: 18334249.

8. Zhang X, Wang B, Li JP. Implications of heparan sulfate and heparanase in neuroinflammation. Matrix Biol. 2014;35:174-81. https://doi.org/10.1016/j.matbio.2013.12.009. PubMed PMID: 24398134.

9. Komarova YA, Kruse K, Mehta D, Malik AB. Protein interactions at endothelial junctions and signaling mechanisms regulating endothelial permeability. Circ Res. 2017;120(1):179206. https://doi.org/10.1161/CIRCRESAHA.116.306534. PubMed PMID: 28057793; PubMed Central PMCID: PMCPMC5225667.

10. Ramos CJ, Antonetti DA. The role of small GTPases and EPAC-Rap signaling in the regulation of the blood-brain and blood-retinal barriers. Tissue Barriers. 2017;5(3):e1339768. https://doi.org/10.1080/21688370.2017.1339768. PubMed PMID: 28632993; PubMed Central PMCID: PMCPMC5571780.

11. Wolburg H, Noell S, Mack A, Wolburg-Buchholz K, Fallier-Becker P. Brain endothelial cells and the glio-vascular complex. Cell Tissue Res. 2009;335(1):75-96. https://doi.org/10.1007/ s00441-008-0658-9. PubMed PMID: 18633647.

12. Liu L, Brown D, McKee M, Lebrasseur NK, Yang D, Albrecht KH, et al. Deletion of Cavin/ PTRF causes global loss of caveolae, dyslipidemia, and glucose intolerance. Cell Metab. 2008;8(4):310-7. https://doi.org/10.1016/j.cmet.2008.07.008. PubMed PMID: 18840361; PubMed Central PMCID: PMCPMC2581738.

13. Echarri A, Del Pozo MA. Caveolae - mechanosensitive membrane invaginations linked to actin filaments. J Cell Sci. 2015;128(15):2747-58. https://doi.org/10.1242/jcs.153940. PubMed PMID: 26159735. 
14. Razani B, Lisanti MP. Caveolin-deficient mice: insights into caveolar function human disease. J Clin Invest. 2001;108(11):1553-61. https://doi.org/10.1172/JCI14611. PubMed PMID: 11733547; PubMed Central PMCID: PMCPMC201001.

15. Daniels BP, Holman DW, Cruz-Orengo L, Jujjavarapu H, Durrant DM, Klein RS. Viral pathogen-associated molecular patterns regulate blood-brain barrier integrity via competing innate cytokine signals. MBio. 2014;5(5):e01476-14. https://doi.org/10.1128/mBio.0147614. PubMed PMID: 25161189; PubMed Central PMCID: PMCPMC4173776.

16. Baruch K, Schwartz M. CNS-specific T cells shape brain function via the choroid plexus. Brain Behav Immun. 2013;34:11-6. https://doi.org/10.1016/j.bbi.2013.04.002. PubMed PMID: 23597431.

17. Brynskikh A, Warren T, Zhu J, Kipnis J. Adaptive immunity affects learning behavior in mice. Brain Behav Immun. 2008;22(6):861-9. https://doi.org/10.1016/j.bbi.2007.12.008. PubMed PMID: 18249087.

18. Derecki NC, Cardani AN, Yang CH, Quinnies KM, Crihfield A, Lynch KR, et al. Regulation of learning and memory by meningeal immunity: a key role for IL-4. J Exp Med. 2010;207(5):1067-80. https://doi.org/10.1084/jem.20091419. PubMed PMID: 20439540; PubMed Central PMCID: PMCPMC2867291.

19. Derecki NC, Quinnies KM, Kipnis J. Alternatively activated myeloid (M2) cells enhance cognitive function in immune compromised mice. Brain Behav Immun. 2011;25(3):37985. https://doi.org/10.1016/j.bbi.2010.11.009. PubMed PMID: 21093578; PubMed Central PMCID: PMCPMC3039052.

20. Kipnis J. Multifaceted interactions between adaptive immunity and the central nervous system. Science. 2016;353(6301):766-71. https://doi.org/10.1126/science.aag2638. PubMed PMID: 27540163; PubMed Central PMCID: PMCPMC5590839.

21. Kipnis J, Cohen H, Cardon M, Ziv Y, Schwartz M. T cell deficiency leads to cognitive dysfunction: implications for therapeutic vaccination for schizophrenia and other psychiatric conditions. Proc Natl Acad Sci U S A. 2004;101(21):8180-5. https://doi.org/10.1073/ pnas.0402268101. PubMed PMID: 15141078; PubMed Central PMCID: PMCPMC419577.

22. Radjavi A, Smirnov I, Derecki N, Kipnis J. Dynamics of the meningeal CD4(+) T-cell repertoire are defined by the cervical lymph nodes and facilitate cognitive task performance in mice. Mol Psychiatry. 2014;19(5):531-3. https://doi.org/10.1038/mp.2013.79. PubMed PMID: 23752249; PubMed Central PMCID: PMCPMC3773254.

23. Engelhardt B, Carare RO, Bechmann I, Flugel A, Laman JD, Weller RO. Vascular, glial, and lymphatic immune gateways of the central nervous system. Acta Neuropathol. 2016;132:317. https://doi.org/10.1007/s00401-016-1606-5. PubMed PMID: 27522506.

24. Louveau A, Smirnov I, Keyes TJ, Eccles JD, Rouhani SJ, Peske JD, et al. Structural and functional features of central nervous system lymphatic vessels. Nature. 2015;523(7560):337-41. https://doi.org/10.1038/nature14432. PubMed PMID: 26030524; PubMed Central PMCID: PMCPMC4506234.

25. Aspelund A, Antila S, Proulx ST, Karlsen TV, Karaman S, Detmar M, et al. A dural lymphatic vascular system that drains brain interstitial fluid and macromolecules. J Exp Med. 2015;212(7):991-9. https://doi.org/10.1084/jem.20142290. PubMed PMID: 26077718; PubMed Central PMCID: PMCPMC4493418.

26. Brinker T, Stopa E, Morrison J, Klinge P. A new look at cerebrospinal fluid circulation. Fluids Barriers CNS. 2014;11:10. https://doi.org/10.1186/2045-8118-11-10. PubMed PMID: 24817998; PubMed Central PMCID: PMCPMC4016637.

27. McCandless EE, Wang Q, Woerner BM, Harper JM, Klein RS. CXCL12 limits inflammation by localizing mononuclear infiltrates to the perivascular space during experimental autoimmune encephalomyelitis. J Immunol. 2006;177(11):8053-64. PubMed PMID: 17114479.

28. McCandless EE, Zhang B, Diamond MS, Klein RS. CXCR4 antagonism increases T cell trafficking in the central nervous system and improves survival from West Nile virus encephalitis. Proc Natl Acad Sci U S A. 2008;105(32):11270-5. https://doi.org/10.1073/pnas.0800898105. PubMed PMID: 18678898; PubMed Central PMCID: PMCPMC2495012. 
29. Durrant DM, Daniels BP, Klein RS. IL-1R1 signaling regulates CXCL12-mediated T cell localization and fate within the central nervous system during West Nile Virus encephalitis. J Immunol. 2014;193(8):4095-106. https://doi.org/10.4049/jimmunol.1401192. PubMed PMID: 25200953; PubMed Central PMCID: PMCPMC4340598.

30. Okada T, Ngo VN, Ekland EH, Forster R, Lipp M, Littman DR, et al. Chemokine requirements for B cell entry to lymph nodes and Peyer's patches. J Exp Med. 2002;196(1):65-75. PubMed PMID: 12093871; PubMed Central PMCID: PMCPMC2194009.

31. Cruz-Orengo L, Holman DW, Dorsey D, Zhou L, Zhang P, Wright M, et al. CXCR7 influences leukocyte entry into the CNS parenchyma by controlling abluminal CXCL12 abundance during autoimmunity. J Exp Med. 2011;208(2):327-39. https://doi.org/10.1084/jem.20102010. PubMed PMID: 21300915; PubMed Central PMCID: PMCPMC3039853.

32. Daneman R, Zhou L, Kebede AA, Barres BA. Pericytes are required for blood-brain barrier integrity during embryogenesis. Nature. 2010;468(7323):562-6. https://doi.org/10.1038/ nature09513. PubMed PMID: 20944625; PubMed Central PMCID: PMCPMC3241506.

33. Nikolakopoulou AM, Zhao Z, Montagne A, Zlokovic BV. Regional early and progressive loss of brain pericytes but not vascular smooth muscle cells in adult mice with disrupted plateletderived growth factor receptor-beta signaling. PLoS One. 2017;12(4):e0176225. https://doi. org/10.1371/journal.pone.0176225. PubMed PMID: 28441414; PubMed Central PMCID: PMCPMC5404855.

34. Maragakis NJ, Rothstein JD. Mechanisms of Disease: astrocytes in neurodegenerative disease. Nat Clin Pract Neurol. 2006;2(12):679-89. https://doi.org/10.1038/ncpneuro0355. PubMed PMID: 17117171.

35. Zonta M, Angulo MC, Gobbo S, Rosengarten B, Hossmann KA, Pozzan T, et al. Neuron-toastrocyte signaling is central to the dynamic control of brain microcirculation. Nat Neurosci. 2003;6(1):43-50. https://doi.org/10.1038/nn980. PubMed PMID: 12469126.

36. Abbott NJ, Ronnback L, Hansson E. Astrocyte-endothelial interactions at the blood-brain barrier. Nat Rev Neurosci. 2006;7(1):41-53. https://doi.org/10.1038/nrn1824. PubMed PMID: 16371949.

37. Nag S. Morphology and properties of astrocytes. Methods Mol Biol. 2011;686:69-100. https://doi.org/10.1007/978-1-60761-938-3_3. PubMed PMID: 21082367.

38. Theis M, Sohl G, Eiberger J, Willecke K. Emerging complexities in identity and function of glial connexins. Trends Neurosci. 2005;28(4):188-95. https://doi.org/10.1016/j. tins.2005.02.006. PubMed PMID: 15808353.

39. Alvarez JI, Katayama T, Prat A. Glial influence on the blood brain barrier. Glia. 2013;61(12):1939-58. https://doi.org/10.1002/glia.22575. PubMed PMID: 24123158; PubMed Central PMCID: PMCPMC4068281.

40. Lee SW, Kim WJ, Choi YK, Song HS, Son MJ, Gelman IH, et al. SSeCKS regulates angiogenesis and tight junction formation in blood-brain barrier. Nat Med. 2003;9(7):900-6. https://doi.org/10.1038/nm889. PubMed PMID: 12808449.

41. Cabezas R, Avila M, Gonzalez J, El-Bacha RS, Baez E, Garcia-Segura LM, et al. Astrocytic modulation of blood brain barrier: perspectives on Parkinson's disease. Front Cell Neurosci. 2014;8:211. https://doi.org/10.3389/fncel.2014.00211. PubMed PMID: 25136294; PubMed Central PMCID: PMCPMC4120694.

42. Balda MS, Gonzalez-Mariscal L, Contreras RG, Macias-Silva M, Torres-Marquez ME, GarciaSainz JA, et al. Assembly and sealing of tight junctions: possible participation of G-proteins, phospholipase C, protein kinase C and calmodulin. J Membr Biol. 1991;122(3):193-202. PubMed PMID: 1920385.

43. Matter K, Balda MS. Signalling to and from tight junctions. Nat Rev Mol Cell Biol. 2003;4(3):225-36. https://doi.org/10.1038/nrm1055. PubMed PMID: 12612641.

44. Ballabh P, Braun A, Nedergaard M. The blood-brain barrier: an overview: structure, regulation, and clinical implications. Neurobiol Dis. 2004;16(1):1-13. https://doi.org/10.1016/j. nbd.2003.12.016. PubMed PMID: 15207256. 
45. Andreeva AY, Piontek J, Blasig IE, Utepbergenov DI. Assembly of tight junction is regulated by the antagonism of conventional and novel protein kinase $\mathrm{C}$ isoforms. Int J Biochem Cell Biol. 2006;38(2):222-33. https://doi.org/10.1016/j.biocel.2005.09.001. PubMed PMID: 16257565.

46. Borisow N, Mori M, Kuwabara S, Scheel M, Paul F. Diagnosis and treatment of NMO spectrum disorder and MOG-encephalomyelitis. Front Neurol. 2018;9:888. https://doi. org/10.3389/fneur.2018.00888. PubMed PMID: 30405519; PubMed Central PMCID: PMCPMC6206299.

47. Kessler RA, Mealy MA, Jimenez-Arango JA, Quan C, Paul F, Lopez R, et al. Anti-aquaporin-4 titer is not predictive of disease course in neuromyelitis optica spectrum disorder: a multicenter cohort study. Mult Scler Relat Disord. 2017;17:198-201. https://doi.org/10.1016/j. msard.2017.08.005. PubMed PMID: 29055457.

48. Wang Y, Zhu M, Liu C, Han J, Lang W, Gao Y, et al. Blood brain barrier permeability could be a biomarker to predict severity of neuromyelitis optica spectrum disorders: a retrospective analysis. Front Neurol. 2018;9:648. https://doi.org/10.3389/fneur.2018.00648. PubMed PMID: 30131763; PubMed Central PMCID: PMCPMC6090143.

49. Saikali P, Cayrol R, Vincent T. Anti-aquaporin-4 auto-antibodies orchestrate the pathogenesis in neuromyelitis optica. Autoimmun Rev. 2009;9(2):132-5. https://doi.org/10.1016/j. autrev.2009.04.004. PubMed PMID: 19389490.

50. Papadopoulos MC, Bennett JL, Verkman AS. Treatment of neuromyelitis optica: state-of-theart and emerging therapies. Nat Rev Neurol. 2014;10(9):493-506. https://doi.org/10.1038/ nrneurol.2014.141. PubMed PMID: 25112508; PubMed Central PMCID: PMCPMC4229040.

51. Asgari N, Berg CT, Morch MT, Khorooshi R, Owens T. Cerebrospinal fluid aquaporin-4immunoglobulin G disrupts blood brain barrier. Ann Clin Transl Neurol. 2015;2(8):857-63. https://doi.org/10.1002/acn3.221. PubMed PMID: 26339679; PubMed Central PMCID: PMCPMC4554446.

52. Shimizu F, Sano Y, Takahashi T, Haruki H, Saito K, Koga M, et al. Sera from neuromyelitis optica patients disrupt the blood-brain barrier. J Neurol Neurosurg Psychiatry. 2012;83(3):288-97. https://doi.org/10.1136/jnnp-2011-300434. PubMed PMID: 22100760.

53. Tomizawa Y, Yokoyama K, Saiki S, Takahashi T, Matsuoka J, Hattori N. Blood-brain barrier disruption is more severe in neuromyelitis optica than in multiple sclerosis and correlates with clinical disability. J Int Med Res. 2012;40(4):1483-91. https://doi. org/10.1177/147323001204000427. PubMed PMID: 22971500.

54. Vincent T, Saikali P, Cayrol R, Roth AD, Bar-Or A, Prat A, et al. Functional consequences of neuromyelitis optica-IgG astrocyte interactions on blood-brain barrier permeability and granulocyte recruitment. J Immunol. 2008;181(8):5730-7. PubMed PMID: 18832732.

55. Hosokawa T, Nakajima H, Doi Y, Sugino M, Kimura F, Hanafusa T, et al. Increased serum matrix metalloproteinase-9 in neuromyelitis optica: implication of disruption of blood-brain barrier. J Neuroimmunol. 2011;236(1-2):81-6. https://doi.org/10.1016/j.jneuroim.2011.04.009. PubMed PMID: 21621856.

56. Spencer JI, Bell JS, DeLuca GC. Vascular pathology in multiple sclerosis: reframing pathogenesis around the blood-brain barrier. J Neurol Neurosurg Psychiatry. 2018;89(1):42-52. https://doi.org/10.1136/jnnp-2017-316011. PubMed PMID: 28860328.

57. Filippi M, Bar-Or A, Piehl F, Preziosa P, Solari A, Vukusic S, et al. Multiple sclerosis. Nat Rev Dis Primers. 2018;4(1):43. https://doi.org/10.1038/s41572-018-0041-4. PubMed PMID: 30410033.

58. Lassmann H. Multiple sclerosis pathology. Cold Spring Harb Perspect Med. 2018;8(3). https://doi.org/10.1101/cshperspect.a028936. PubMed PMID: 29358320.

59. Claudio L, Raine CS, Brosnan CF. Evidence of persistent blood-brain barrier abnormalities in chronic-progressive multiple sclerosis. Acta Neuropathol. 1995;90(3):228-38. PubMed PMID: 8525795.

60. Uchida Y, Sumiya T, Tachikawa M, Yamakawa T, Murata S, Yagi Y, et al. Involvement of claudin-11 in disruption of blood-brain, -spinal cord, and -arachnoid barriers in multiple sclerosis. Mol Neurobiol. 2018;56:2039. https://doi.org/10.1007/s12035-018-1207-5. PubMed PMID: 29984400. 
61. Cruz-Orengo L, Daniels BP, Dorsey D, Basak SA, Grajales-Reyes JG, McCandless EE, et al. Enhanced sphingosine-1-phosphate receptor 2 expression underlies female CNS autoimmunity susceptibility. J Clin Invest. 2014;124(6):2571-84. https://doi.org/10.1172/JCI73408. PubMed PMID: 24812668; PubMed Central PMCID: PMCPMC4089451.

62. Motyl J, Strosznajder JB. Sphingosine kinase 1/sphingosine-1-phosphate receptors dependent signalling in neurodegenerative diseases. The promising target for neuroprotection in Parkinson's disease. Pharmacol Rep. 2018;70(5):1010-4. https://doi.org/10.1016/j. pharep.2018.05.002. PubMed PMID: 30138818.

63. Tsai HC, Han MH. Sphingosine-1-Phosphate (S1P) and S1P signaling pathway: therapeutic targets in autoimmunity and inflammation. Drugs. 2016;76(11):1067-79. https://doi. org/10.1007/s40265-016-0603-2. PubMed PMID: 27318702.

64. Healy LM, Antel JP. Sphingosine-1-Phosphate receptors in the central nervous and immune systems. Curr Drug Targets. 2016;17(16):1841-50. PubMed PMID: 26424391.

65. McCandless EE, Piccio L, Woerner BM, Schmidt RE, Rubin JB, Cross AH, et al. Pathological expression of CXCL12 at the blood-brain barrier correlates with severity of multiple sclerosis. Am J Pathol. 2008;172(3):799-808. https://doi.org/10.2353/ajpath.2008.070918. PubMed PMID: 18276777; PubMed Central PMCID: PMCPMC2258272.

66. McGinley AM, Edwards SC, Raverdeau M, Mills KHG. Th17cells, gammadelta T cells and their interplay in EAE and multiple sclerosis. J Autoimmun. 2018. https://doi.org/10.1016/j. jaut.2018.01.001. PubMed PMID: 29395738.

67. McCandless EE, Budde M, Lees JR, Dorsey D, Lyng E, Klein RS. IL-1R signaling within the central nervous system regulates CXCL12 expression at the blood-brain barrier and disease severity during experimental autoimmune encephalomyelitis. J Immunol. 2009;183(1):61320. https://doi.org/10.4049/jimmunol.0802258. PubMed PMID: 19535637; PubMed Central PMCID: PMCPMC2892701.

68. Champagne E. gammadelta $\mathrm{T}$ cell receptor ligands and modes of antigen recognition. Arch Immunol Ther Exp. 2011;59(2):117-37. https://doi.org/10.1007/s00005-011-0118-1. PubMed PMID: 21298486; PubMed Central PMCID: PMCPMC3317888.

69. Axtell RC, de Jong BA, Boniface K, van der Voort LF, Bhat R, De Sarno P, et al. T helper type 1 and 17 cells determine efficacy of interferon-beta in multiple sclerosis and experimental encephalomyelitis. Nat Med. 2010;16(4):406-12. https://doi.org/10.1038/nm.2110. PubMed PMID: 20348925; PubMed Central PMCID: PMCPMC3042885.

70. Toplak N, Blazina S, Avcin T. The role of IL-1 inhibition in systemic juvenile idiopathic arthritis: current status and future perspectives. Drug Des Devel Ther. 2018;12:1633-43. https://doi.org/10.2147/DDDT.S114532. PubMed PMID: 29922038; PubMed Central PMCID: PMCPMC5996857.

71. Kim BS, Park YJ, Chung Y. Targeting IL-17 in autoimmunity and inflammation. Arch Pharm Res. 2016;39(11):1537-47. https://doi.org/10.1007/s12272-016-0823-8. PubMed PMID: 27576555.

72. Hanes MS, Salanga CL, Chowdry AB, Comerford I, McColl SR, Kufareva I, et al. Dual targeting of the chemokine receptors CXCR4 and ACKR3 with novel engineered chemokines. J Biol Chem. 2015;290(37):22385-97. https://doi.org/10.1074/jbc.M115.675108. PubMed PMID: 26216880; PubMed Central PMCID: PMCPMC4566214.

73. van Horssen J, Brink BP, de Vries HE, van der Valk P, Bo L. The blood-brain barrier in cortical multiple sclerosis lesions. J Neuropathol Exp Neurol. 2007;66(4):321-8. https://doi. org/10.1097/nen.0b013e318040b2de. PubMed PMID: 17413323.

74. Akaishi T, Takahashi T, Nakashima I. Oligoclonal bands and periventricular lesions in multiple sclerosis will not increase blood-brain barrier permeability. J Neurol Sci. 2018;387:129_ 33. https://doi.org/10.1016/j.jns.2018.02.020. PubMed PMID: 29571849.

75. Lee NJ, Ha SK, Sati P, Absinta M, Luciano NJ, Lefeuvre JA, et al. Spatiotemporal distribution of fibrinogen in marmoset and human inflammatory demyelination. Brain. 2018;141(6):1637-49. https://doi.org/10.1093/brain/awy082. PubMed PMID: 29688408; PubMed Central PMCID: PMCPMC5972667. 
76. Lucas MJ, Brouwer MC, van de Beek D. Neurological sequelae of bacterial meningitis. J Infect. 2016;73(1):18-27. https://doi.org/10.1016/j.jinf.2016.04.009. PubMed PMID: 27105658.

77. Neal JW, Gasque P. How does the brain limit the severity of inflammation and tissue injury during bacterial meningitis? J Neuropathol Exp Neurol. 2013;72(5):370-85. https://doi. org/10.1097/NEN.0b013e3182909f2f. PubMed PMID: 23584204.

78. Iovino F, Engelen-Lee JY, Brouwer M, van de Beek D, van der Ende A, Valls Seron M, et al. pIgR and PECAM-1 bind to pneumococcal adhesins RrgA and PspC mediating bacterial brain invasion. J Exp Med. 2017;214(6):1619-30. https://doi.org/10.1084/jem.20161668. PubMed PMID: 28515075; PubMed Central PMCID: PMCPMC5461002.

79. Barichello T, dos Santos I, Savi GD, Simoes LR, Silvestre T, Comim CM, et al. TNF-alpha, IL-1beta, IL-6, and cinc-1 levels in rat brain after meningitis induced by Streptococcus pneumoniae. J Neuroimmunol. 2010;221(1-2):42-5. https://doi.org/10.1016/j.jneuroim.2010.02.009. PubMed PMID: 20202693.

80. Barichello T, Generoso JS, Silvestre C, Costa CS, Carrodore MM, Cipriano AL, et al. Circulating concentrations, cerebral output of the CINC-1 and blood-brain barrier disruption in Wistar rats after pneumococcal meningitis induction. Eur J Clin Microbiol Infect Dis. 2012;31(8):2005-9. https://doi.org/10.1007/s10096-011-1533-2. PubMed PMID: 22302624.

81. Storz C, Schutz C, Tluway A, Matuja W, Schmutzhard E, Winkler AS. Clinical findings and management of patients with meningitis with an emphasis on Haemophilus influenzae meningitis in rural Tanzania. J Neurol Sci. 2016;366:52-8. https://doi.org/10.1016/j. jns.2016.04.044. PubMed PMID: 27288776.

82. Zysk G, Schneider-Wald BK, Hwang JH, Bejo L, Kim KS, Mitchell TJ, et al. Pneumolysin is the main inducer of cytotoxicity to brain microvascular endothelial cells caused by Streptococcus pneumoniae. Infect Immun. 2001;69(2):845-52. https://doi.org/10.1128/IAI.69.2.845852.2001. PubMed PMID: 11159977; PubMed Central PMCID: PMCPMC97961.

83. Coureuil M, Lecuyer H, Bourdoulous S, Nassif X. A journey into the brain: insight into how bacterial pathogens cross blood-brain barriers. Nat Rev Microbiol. 2017;15(3):149-59. https://doi.org/10.1038/nrmicro.2016.178. PubMed PMID: 28090076.

84. Drevets DA, Dillon MJ, Schawang JS, Van Rooijen N, Ehrchen J, Sunderkotter C, et al. The Ly-6Chigh monocyte subpopulation transports Listeria monocytogenes into the brain during systemic infection of mice. J Immunol. 2004;172(7):4418-24. PubMed PMID: 15034057.

85. Drevets DA, Leenen PJ, Greenfield RA. Invasion of the central nervous system by intracellular bacteria. Clin Microbiol Rev. 2004;17(2):323-47. PubMed PMID: 15084504; PubMed Central PMCID: PMCPMC387409.

86. Grundler T, Quednau N, Stump C, Orian-Rousseau V, Ishikawa H, Wolburg H, et al. The surface proteins InlA and InlB are interdependently required for polar basolateral invasion by Listeria monocytogenes in a human model of the blood-cerebrospinal fluid barrier. Microbes Infect. 2013;15(4):291-301. https://doi.org/10.1016/j.micinf.2012.12.005. PubMed PMID: 23376167.

87. Kayal S, Lilienbaum A, Join-Lambert O, Li X, Israel A, Berche P. Listeriolysin O secreted by Listeria monocytogenes induces NF-kappaB signalling by activating the IkappaB kinase complex. Mol Microbiol. 2002;44(5):1407-19. PubMed PMID: 12028384.

88. Bartt R. Listeria and atypical presentations of Listeria in the central nervous system. Semin Neurol. 2000;20(3):361-73. https://doi.org/10.1055/s-2000-9398. PubMed PMID: 11051300.

89. Inglesby TV, O'Toole T, Henderson DA, Bartlett JG, Ascher MS, Eitzen E, et al. Anthrax as a biological weapon, 2002: updated recommendations for management. JAMA. 2002;287(17):2236-52. PubMed PMID: 11980524.

90. Ramarao N, Lereclus D. The InhA1 metalloprotease allows spores of the B. cereus group to escape macrophages. Cell Microbiol. 2005;7(9):1357-64. https://doi.org/10.1111/j.14625822.2005.00562.x. PubMed PMID: 16098222.

91. Ebrahimi CM, Kern JW, Sheen TR, Ebrahimi-Fardooee MA, van Sorge NM, Schneewind O, et al. Penetration of the blood-brain barrier by Bacillus anthracis requires the $\mathrm{pXO1-encoded}$ BslA protein. J Bacteriol. 2009;191(23):7165-73. https://doi.org/10.1128/JB.00903-09. PubMed PMID: 19820089; PubMed Central PMCID: PMCPMC2786561. 
92. Kern J, Schneewind O. BslA, the S-layer adhesin of B. anthracis, is a virulence factor for anthrax pathogenesis. Mol Microbiol. 2010;75(2):324-32. https://doi.org/10.1111/ j.1365-2958.2009.06958.x. PubMed PMID: 19906175; PubMed Central PMCID: PMCPMC2828814.

93. Moayeri M, Leppla SH, Vrentas C, Pomerantsev AP, Liu S. Anthrax pathogenesis. Annu Rev Microbiol. 2015;69:185-208. https://doi.org/10.1146/annurev-micro-091014-104523. PubMed PMID: 26195305.

94. Scheifele D. Hib conjugate vaccines: lessons learned. Int J Clin Pract Suppl. 2001;(118):8-9. PubMed PMID: 11715364.

95. Al-Obaidi MMJ, Desa MNM. Mechanisms of blood brain barrier disruption by different types of bacteria, and bacterial-host interactions facilitate the bacterial pathogen invading the brain. Cell Mol Neurobiol. 2018;38(7):1349-68. https://doi.org/10.1007/s10571-018-06092. PubMed PMID: 30117097.

96. Orihuela CJ, Mahdavi J, Thornton J, Mann B, Wooldridge KG, Abouseada N, et al. Laminin receptor initiates bacterial contact with the blood brain barrier in experimental meningitis models. J Clin Invest. 2009;119(6):1638-46. https://doi.org/10.1172/JCI36759. PubMed PMID: 19436113; PubMed Central PMCID: PMCPMC2689107.

97. Saez-Llorens X, Jafari HS, Severien C, Parras F, Olsen KD, Hansen EJ, et al. Enhanced attenuation of meningeal inflammation and brain edema by concomitant administration of anti-CD18 monoclonal antibodies and dexamethasone in experimental Haemophilus meningitis. J Clin Invest. 1991;88(6):2003-11. https://doi.org/10.1172/JCI115527. PubMed PMID: 1684364; PubMed Central PMCID: PMCPMC295788.

98. Roos KL. Acute bacterial meningitis. Semin Neurol. 2000;20(3):293-306. https://doi. org/10.1055/s-2000-9393. PubMed PMID: 11051294.

99. Oordt-Speets AM, Bolijn R, van Hoorn RC, Bhavsar A, Kyaw MH. Global etiology of bacterial meningitis: a systematic review and meta-analysis. PLoS One. 2018;13(6):e0198772. https://doi.org/10.1371/journal.pone.0198772. PubMed PMID: 29889859; PubMed Central PMCID: PMCPMC5995389 performed under contract by Pallas Health Research and Consultancy, Rotterdam, The Netherlands. AMO, RB, and RCH are employees of Pallas Health Research and Consultancy, Rotterdam, The Netherlands. AB and MHK are employees of Sanofi-Pasteur. This does not alter our adherence to PLOS ONE policies on sharing data and materials.

100. Sa ECC, Griffiths NJ, Murillo I, Virji M. Neisseria meningitidis Opc invasin binds to the cytoskeletal protein alpha-actinin. Cell Microbiol. 2009;11(3):389-405. https://doi. org/10.1111/j.1462-5822.2008.01262.x. PubMed PMID: 19016781; PubMed Central PMCID: PMCPMC2688670.

101. Virji M. Pathogenic neisseriae: surface modulation, pathogenesis and infection control. Nat Rev Microbiol. 2009;7(4):274-86. https://doi.org/10.1038/nrmicro2097. PubMed PMID: 19287450.

102. Cain MD, Salimi H, Gong Y, Yang L, Hamilton SL, Heffernan JR, et al. Virus entry and replication in the brain precedes blood-brain barrier disruption during intranasal alphavirus infection. J Neuroimmunol. 2017;308:118-30. https://doi.org/10.1016/j.jneuroim.2017.04.008. PubMed PMID: 28501330; PubMed Central PMCID: PMCPMC5694394.

103. Li F, Wang Y, Yu L, Cao S, Wang K, Yuan J, et al. Viral infection of the central nervous system and neuroinflammation precede blood-brain barrier disruption during Japanese encephalitis virus infection. J Virol. 2015;89(10):5602-14. https://doi.org/10.1128/JVI.00143-15. PubMed PMID: 25762733; PubMed Central PMCID: PMCPMC4442524.

104. Roe K, Kumar M, Lum S, Orillo B, Nerurkar VR, West VS. Nile virus-induced disruption of the blood-brain barrier in mice is characterized by the degradation of the junctional complex proteins and increase in multiple matrix metalloproteinases. J Gen Virol. 2012;93(Pt 6):1193-203. https://doi.org/10.1099/vir.0.040899-0. PubMed PMID: 22398316; PubMed Central PMCID: PMCPMC3755517.

105. Schafer A, Brooke CB, Whitmore AC, Johnston RE. The role of the blood-brain barrier during Venezuelan equine encephalitis virus infection. J Virol. 2011;85(20):10682-90. https:// doi.org/10.1128/JVI.05032-11. PubMed PMID: 21849461; PubMed Central PMCID: PMCPMC3187510. 
106. Salimi H, Cain MD, Klein RS. Encephalitic arboviruses: emergence, clinical presentation, and neuropathogenesis. Neurotherapeutics. 2016;13(3):514-34. https://doi.org/10.1007/s13311016-0443-5. PubMed PMID: 27220616; PubMed Central PMCID: PMCPMC4965410.

107. Gralinski LE, Ashley SL, Dixon SD, Spindler KR. Mouse adenovirus type 1-induced breakdown of the blood-brain barrier. J Virol. 2009;83(18):9398-410. https://doi.org/10.1128/ JVI.00954-09. PubMed PMID: 19570856; PubMed Central PMCID: PMCPMC2738240.

108. Kajon AE, Brown CC, Spindler KR. Distribution of mouse adenovirus type 1 in intraperitoneally and intranasally infected adult outbred mice. J Virol. 1998;72(2):1219-23. PubMed PMID: 9445021; PubMed Central PMCID: PMCPMC124599.

109. Wang K, Wang H, Lou W, Ma L, Li Y, Zhang N, et al. IP-10 promotes blood-brain barrier damage by inducing tumor necrosis factor alpha production in Japanese encephalitis. Front Immunol. 2018;9:1148. https://doi.org/10.3389/fimmu.2018.01148. PubMed PMID: 29910805 ; PubMed Central PMCID: PMCPMC5992377.

110. Dallasta LM, Pisarov LA, Esplen JE, Werley JV, Moses AV, Nelson JA, et al. Blood-brain barrier tight junction disruption in human immunodeficiency virus-1 encephalitis. Am J Pathol. 1999;155(6):1915-27. https://doi.org/10.1016/S0002-9440(10)65511-3. PubMed PMID: 10595922; PubMed Central PMCID: PMCPMC1866950.

111. Bleau C, Filliol A, Samson M, Lamontagne L. Brain invasion by mouse hepatitis virus depends on impairment of tight junctions and beta interferon production in brain microvascular endothelial cells. J Virol. 2015;89(19):9896-908. https://doi.org/10.1128/JVI.01501-15. PubMed PMID: 26202229; PubMed Central PMCID: PMCPMC4577898.

112. Song HY, Ju SM, Seo WY, Goh AR, Lee JK, Bae YS, et al. Nox2-based NADPH oxidase mediates HIV-1 Tat-induced up-regulation of VCAM-1/ICAM-1 and subsequent monocyte adhesion in human astrocytes. Free Radic Biol Med. 2011;50(5):576-84. https://doi. org/10.1016/j.freeradbiomed.2010.12.019. PubMed PMID: 21172429.

113. Keck F, Brooks-Faulconer T, Lark T, Ravishankar P, Bailey C, Salvador-Morales C, et al. Altered mitochondrial dynamics as a consequence of Venezuelan Equine encephalitis virus infection. Virulence. 2017;8(8):1849-66. https://doi.org/10.1080/21505594.2016.1276690. PubMed PMID: 28075229; PubMed Central PMCID: PMCPMC5810500.

114. Masanetz S, Lehmann MH. HIV-1 Nef increases astrocyte sensitivity towards exogenous hydrogen peroxide. Virol J. 2011;8:35. https://doi.org/10.1186/1743-422X-8-35. PubMed PMID: 21255447; PubMed Central PMCID: PMCPMC3038946.

115. Louboutin JP, Agrawal L, Reyes BA, Van Bockstaele EJ, Strayer DS. HIV-1 gp120induced injury to the blood-brain barrier: role of metalloproteinases 2 and 9 and relationship to oxidative stress. J Neuropathol Exp Neurol. 2010;69(8):801-16. https://doi. org/10.1097/NEN.0b013e3181e8c96f. PubMed PMID: 20613638; PubMed Central PMCID: PMCPMC4707960.

116. Thangaraj A, Periyasamy P, Liao K, Bendi VS, Callen S, Pendyala G, et al. HIV-1 TATmediated microglial activation: role of mitochondrial dysfunction and defective mitophagy. Autophagy. 2018;14(9):1596-619. https://doi.org/10.1080/15548627.2018.1476810. PubMed PMID: 29966509; PubMed Central PMCID: PMCPMC6135576.

117. Wang T, Campbell RV, Yi MK, Lemon SM, Weinman SA. Role of Hepatitis C virus core protein in viral-induced mitochondrial dysfunction. J Viral Hepat. 2010;17(11):784-93. https:// doi.org/10.1111/j.1365-2893.2009.01238.x. PubMed PMID: 20002299; PubMed Central PMCID: PMCPMC2970657.

118. Wang P, Dai J, Bai F, Kong KF, Wong SJ, Montgomery RR, et al. Matrix metalloproteinase 9 facilitates West Nile virus entry into the brain. J Virol. 2008;82(18):8978-85. https:// doi.org/10.1128/JVI.00314-08. PubMed PMID: 18632868; PubMed Central PMCID: PMCPMC2546894.

119. Ashley SL, Pretto CD, Stier MT, Kadiyala P, Castro-Jorge L, Hsu TH, et al. Matrix metalloproteinase activity in infections by an encephalitic virus, mouse adenovirus type 1 . J Virol. 2017;91(6). https://doi.org/10.1128/JVI.01412-16. PubMed PMID: 28053109; PubMed Central PMCID: PMCPMC5331797. 
120. Chang CY, Li JR, Chen WY, Ou YC, Lai CY, Hu YH, et al. Disruption of in vitro endothelial barrier integrity by Japanese encephalitis virus-Infected astrocytes. Glia. 2015;63(11):191532. https://doi.org/10.1002/glia.22857. PubMed PMID: 25959931.

121. Loffek S, Schilling O, Franzke CW. Series "matrix metalloproteinases in lung health and disease": biological role of matrix metalloproteinases: a critical balance. Eur Respir J. 2011;38(1):191-208. https://doi.org/10.1183/09031936.00146510. PubMed PMID: 21177845.

122. Xing Y, Shepherd N, Lan J, Li W, Rane S, Gupta SK, et al. MMPs/TIMPs imbalances in the peripheral blood and cerebrospinal fluid are associated with the pathogenesis of HIV1-associated neurocognitive disorders. Brain Behav Immun. 2017;65:161-72. https://doi. org/10.1016/j.bbi.2017.04.024. PubMed PMID: 28487203; PubMed Central PMCID: PMCPMC5793222.

123. Schafer A, Whitmore AC, Konopka JL, Johnston RE. Replicon particles of Venezuelan equine encephalitis virus as a reductionist murine model for encephalitis. J Virol. 2009;83(9):427586. https://doi.org/10.1128/JVI.02383-08. PubMed PMID: 19225006; PubMed Central PMCID: PMCPMC2668494.

124. Andras IE, Pu H, Tian J, Deli MA, Nath A, Hennig B, et al. Signaling mechanisms of HIV-1 Tat-induced alterations of claudin-5 expression in brain endothelial cells. J Cereb Blood Flow Metab. 2005;25(9):1159-70. https://doi.org/10.1038/sj.jcbfm.9600115. PubMed PMID: 15815581.

125. Aghajanian A, Wittchen ES, Campbell SL, Burridge K. Direct activation of RhoA by reactive oxygen species requires a redox-sensitive motif. PLoS One. 2009;4(11):e8045. https://doi. org/10.1371/journal.pone.0008045. PubMed PMID: 19956681; PubMed Central PMCID: PMCPMC2778012.

126. Harijith A, Ebenezer DL, Natarajan V. Reactive oxygen species at the crossroads of inflammasome and inflammation. Front Physiol. 2014;5:352. https://doi.org/10.3389/ fphys.2014.00352. PubMed PMID: 25324778; PubMed Central PMCID: PMCPMC4179323.

127. Afonso PV, Ozden S, Cumont MC, Seilhean D, Cartier L, Rezaie P, et al. Alteration of bloodbrain barrier integrity by retroviral infection. PLoS Pathog. 2008;4(11):e1000205. https:// doi.org/10.1371/journal.ppat.1000205. PubMed PMID: 19008946; PubMed Central PMCID: PMCPMC2575404.

128. Park BH, Lavi E, Blank KJ, Gaulton GN. Intracerebral hemorrhages and syncytium formation induced by endothelial cell infection with a murine leukemia virus. J Virol. 1993;67(10):601524. PubMed PMID: 8396666; PubMed Central PMCID: PMCPMC238022.

129. Erbar S, Maisner A. Nipah virus infection and glycoprotein targeting in endothelial cells. Virol J. 2010;7:305. https://doi.org/10.1186/1743-422X-7-305. PubMed PMID: 21054904; PubMed Central PMCID: PMCPMC2991316.

130. Rockx B, Brining D, Kramer J, Callison J, Ebihara H, Mansfield K, et al. Clinical outcome of henipavirus infection in hamsters is determined by the route and dose of infection. J Virol. 2011;85(15):7658-71. https://doi.org/10.1128/JVI.00473-11. PubMed PMID: 21593160; PubMed Central PMCID: PMCPMC3147900.

131. Wong KT, Robertson T, Ong BB, Chong JW, Yaiw KC, Wang LF, et al. Human Hendra virus infection causes acute and relapsing encephalitis. Neuropathol Appl Neurobiol. 2009;35(3):296-305. https://doi.org/10.1111/j.1365-2990.2008.00991.x. PubMed PMID: 19473296.

132. Al-Obaidi MMJ, Bahadoran A, Har LS, Mui WS, Rajarajeswaran J, Zandi K, et al. Japanese encephalitis virus disrupts blood-brain barrier and modulates apoptosis proteins in THBMEC cells. Virus Res. 2017;233:17-28. https://doi.org/10.1016/j.virusres.2017.02.012. PubMed PMID: 28279803.

133. Westendorp MO, Frank R, Ochsenbauer C, Stricker K, Dhein J, Walczak H, et al. Sensitization of T cells to CD95-mediated apoptosis by HIV-1 Tat and gp120. Nature. 1995;375(6531):497500. https://doi.org/10.1038/375497a0. PubMed PMID: 7539892. 
134. Pu H, Hayashi K, Andras IE, Eum SY, Hennig B, Toborek M. Limited role of COX-2 in HIV Tat-induced alterations of tight junction protein expression and disruption of the bloodbrain barrier. Brain Res. 2007;1184:333-44. https://doi.org/10.1016/j.brainres.2007.09.063. PubMed PMID: 17976544.

135. Davidson DC, Hirschman MP, Sun A, Singh MV, Kasischke K, Maggirwar SB. Excess soluble CD40L contributes to blood brain barrier permeability in vivo: implications for HIV-associated neurocognitive disorders. PLoS One. 2012;7(12):e51793. https://doi. org/10.1371/journal.pone.0051793. PubMed PMID: 23251626; PubMed Central PMCID: PMCPMC3520914.

136. Jones LD, Jackson JW, Maggirwar SB. Modeling HIV-1 induced neuroinflammation in mice: role of platelets in mediating blood-brain barrier dysfunction. PLoS One. 2016;11(3):e0151702. https://doi.org/10.1371/journal.pone.0151702. PubMed PMID: 26986758; PubMed Central PMCID: PMCPMC4795798.

137. Corrales-Medina VF, Simkins J, Chirinos JA, Serpa JA, Horstman LL, Jy W, et al. Increased levels of platelet microparticles in HIV-infected patients with good response to highly active antiretroviral therapy. J Acquir Immune Defic Syndr. 2010;54(2):217-8. https://doi. org/10.1097/QAI.0b013e3181c8f4c9. PubMed PMID: 20505474.

138. Sui Z, Sniderhan LF, Schifitto G, Phipps RP, Gelbard HA, Dewhurst S, et al. Functional synergy between CD40 ligand and HIV-1 Tat contributes to inflammation: implications in HIV type 1 dementia. J Immunol. 2007;178(5):3226-36. PubMed PMID: 17312171.

139. Vibin M, Siva Priya SG, NR B, Sasikala V, Sahasranamam V, Abraham A. Broccoli regulates protein alterations and cataractogenesis in selenite models. Curr Eye Res. 2010;35(2):99107. https://doi.org/10.3109/02713680903428991. PubMed PMID: 20136419.

140. Carty M, Reinert L, Paludan SR, Bowie AG. Innate antiviral signalling in the central nervous system. Trends Immunol. 2014;35(2):79-87. https://doi.org/10.1016/j.it.2013.10.012. PubMed PMID: 24316012.

141. Errett JS, Suthar MS, McMillan A, Diamond MS, Gale M Jr. The essential, nonredundant roles of RIG-I and MDA5 in detecting and controlling West Nile virus infection. J Virol. 2013;87(21):11416-25. https://doi.org/10.1128/JVI.01488-13. PubMed PMID: 23966395; PubMed Central PMCID: PMCPMC3807316.

142. Reinert LS, Harder L, Holm CK, Iversen MB, Horan KA, Dagnaes-Hansen F, et al. TLR3 deficiency renders astrocytes permissive to herpes simplex virus infection and facilitates establishment of CNS infection in mice. J Clin Invest. 2012;122(4):1368-76. https://doi.org/10.1172/ JCI60893. PubMed PMID: 22426207; PubMed Central PMCID: PMCPMC3314467.

143. Suthar MS, Ma DY, Thomas S, Lund JM, Zhang N, Daffis S, et al. IPS-1 is essential for the control of West Nile virus infection and immunity. PLoS Pathog. 2010;6(2):e1000757. https://doi.org/10.1371/journal.ppat.1000757. PubMed PMID: 20140199; PubMed Central PMCID: PMCPMC2816698.

144. Wang T, Town T, Alexopoulou L, Anderson JF, Fikrig E, Flavell RA. Toll-like receptor 3 mediates West Nile virus entry into the brain causing lethal encephalitis. Nat Med. 2004;10(12):1366-73. https://doi.org/10.1038/nm1140. PubMed PMID: 15558055.

145. Daffis S, Samuel MA, Suthar MS, Gale M, Jr., Diamond MS. Toll-like receptor 3 has a protective role against West Nile virus infection. J Virol 2008;82(21):10349-10358. doi: https://doi.org/10.1128/JVI.00935-08. PubMed PMID: 18715906; PubMed Central PMCID: PMCPMC2573187.

146. Menager P, Roux P, Megret F, Bourgeois JP, Le Sourd AM, Danckaert A, et al. Toll-like receptor 3 (TLR3) plays a major role in the formation of rabies virus Negri Bodies. PLoS Pathog. 2009;5(2):e1000315. https://doi.org/10.1371/journal.ppat.1000315. PubMed PMID: 19247444; PubMed Central PMCID: PMCPMC2642728.

147. Ramos HJ, Lanteri MC, Blahnik G, Negash A, Suthar MS, Brassil MM, et al. IL-1beta signaling promotes CNS-intrinsic immune control of West Nile virus infection. PLoS Pathog. 2012;8(11):e1003039. https://doi.org/10.1371/journal.ppat.1003039. PubMed PMID: 23209411; PubMed Central PMCID: PMCPMC3510243. 
148. Kaushik DK, Gupta M, Kumawat KL, Basu A. NLRP3 inflammasome: key mediator of neuroinflammation in murine Japanese encephalitis. PLoS One. 2012;7(2):e32270. https://doi. org/10.1371/journal.pone.0032270. PubMed PMID: 22393394; PubMed Central PMCID: PMCPMC3290554.

149. Wang Y, Jin S, Sonobe Y, Cheng Y, Horiuchi H, Parajuli B, et al. Interleukin-1beta induces blood-brain barrier disruption by downregulating Sonic hedgehog in astrocytes. PLoS One. 2014;9(10):e110024. https://doi.org/10.1371/journal.pone.0110024. PubMed PMID: 25313834; PubMed Central PMCID: PMCPMC4196962.

150. Marques CP, Hu S, Sheng W, Lokensgard JR. Microglial cells initiate vigorous yet nonprotective immune responses during HSV-1 brain infection. Virus Res. 2006;121(1):1-10. https://doi.org/10.1016/j.virusres.2006.03.009. PubMed PMID: 16621100.

151. Sun J, Zheng JH, Zhao M, Lee S, Goldstein H. Increased in vivo activation of microglia and astrocytes in the brains of mice transgenic for an infectious R5 human immunodeficiency virus type 1 provirus and for $\mathrm{CD} 4$-specific expression of human cyclin $\mathrm{T} 1$ in response to stimulation by lipopolysaccharides. J Virol. 2008;82(11):5562-72. https://doi.org/10.1128/ JVI.02618-07. PubMed PMID: 18353948; PubMed Central PMCID: PMCPMC2395169.

152. Vasek MJ, Garber C, Dorsey D, Durrant DM, Bollman B, Soung A, et al. A complementmicroglial axis drives synapse loss during virus-induced memory impairment. Nature. 2016;534(7608):538-43. https://doi.org/10.1038/nature18283. PubMed PMID: 27337340.

153. da Fonseca AC, Matias D, Garcia C, Amaral R, Geraldo LH, Freitas C, et al. The impact of microglial activation on blood-brain barrier in brain diseases. Front Cell Neurosci. 2014;8:362. https://doi.org/10.3389/fncel.2014.00362. PubMed PMID: 25404894; PubMed Central PMCID: PMCPMC4217497.

154. Chhatbar C, Detje CN, Grabski E, Borst K, Spanier J, Ghita L, et al. Type I interferon receptor signaling of neurons and astrocytes regulates microglia activation during viral encephalitis. Cell Rep. 2018;25(1):118-29 e4. https://doi.org/10.1016/j.celrep.2018.09.003. PubMed PMID: 30282022.

155. Fekete R, Cserep C, Lenart N, Toth K, Orsolits B, Martinecz B, et al. Microglia control the spread of neurotropic virus infection via P2Y12 signalling and recruit monocytes through P2Y12-independent mechanisms. Acta Neuropathol. 2018;136(3):461-82. https://doi. org/10.1007/s00401-018-1885-0. PubMed PMID: 30027450; PubMed Central PMCID: PMCPMC6096730.

156. Wheeler DL, Sariol A, Meyerholz DK, Perlman S. Microglia are required for protection against lethal coronavirus encephalitis in mice. J Clin Invest. 2018;128(3):931-43. https://doi.org/10.1172/JCI97229. PubMed PMID: 29376888; PubMed Central PMCID: PMCPMC5824854.

157. Kallfass C, Ackerman A, Lienenklaus S, Weiss S, Heimrich B, Staeheli P. Visualizing production of beta interferon by astrocytes and microglia in brain of La Crosse virus-infected mice. J Virol. 2012;86(20):11223-30. https://doi.org/10.1128/JVI.01093-12. PubMed PMID: 22875966; PubMed Central PMCID: PMCPMC3457137.

158. Pfefferkorn C, Kallfass C, Lienenklaus S, Spanier J, Kalinke U, Rieder M, et al. Abortively infected astrocytes appear to represent the main source of interferon beta in the virus-infected brain. J Virol. 2016;90(4):2031-8. https://doi.org/10.1128/JVI.02979-15. PubMed PMID: 26656686; PubMed Central PMCID: PMCPMC4733997.

159. Hwang M, Bergmann CC. Alpha/beta interferon (IFN-alpha/beta) signaling in astrocytes mediates protection against viral encephalomyelitis and regulates IFN-gamma-dependent responses. J Virol. 2018;92(10) https://doi.org/10.1128/JVI.01901-17. PubMed PMID: 29491163; PubMed Central PMCID: PMCPMC5923078.

160. Ye J, Jiang R, Cui M, Zhu B, Sun L, Wang Y, et al. Etanercept reduces neuroinflammation and lethality in mouse model of Japanese encephalitis. J Infect Dis. 2014;210(6):875-89. https:// doi.org/10.1093/infdis/jiu179. PubMed PMID: 24652493.

161. Man SM, Karki R, Kanneganti TD. Molecular mechanisms and functions of pyroptosis, inflammatory caspases and inflammasomes in infectious diseases. Immunol Rev. 2017;277(1):61-75. https://doi.org/10.1111/imr.12534. PubMed PMID: 28462526; PubMed Central PMCID: PMCPMC5416822. 
162. Yogarajah T, Ong KC, Perera D, Wong KT. AIM2 inflammasome-mediated pyroptosis in enterovirus A71-infected neuronal cells restricts viral replication. Sci Rep. 2017;7(1):5845. https://doi.org/10.1038/s41598-017-05589-2. PubMed PMID: 28724943; PubMed Central PMCID: PMCPMC5517550.

163. de Sousa JR, Azevedo R, Martins Filho AJ, de Araujo MTF, Cruz E, Vasconcelos BCB, et al. In situ inflammasome activation results in severe damage to the central nervous system in fatal Zika virus microcephaly cases. Cytokine. 2018;111:255-64. https://doi.org/10.1016/j. cyto.2018.08.008. PubMed PMID: 30199767.

164. Vijay R, Fehr AR, Janowski AM, Athmer J, Wheeler DL, Grunewald M, et al. Virus-induced inflammasome activation is suppressed by prostaglandin D2/DP1 signaling. Proc Natl Acad Sci U S A. 2017;114(27):E5444-E53. https://doi.org/10.1073/pnas.1704099114. PubMed PMID: 28630327; PubMed Central PMCID: PMCPMC5502630.

165. Bortell N, Flynn C, Conti B, Fox HS, Marcondes MCG. Osteopontin impacts West Nile virus pathogenesis and resistance by regulating inflammasome components and cell death in the central nervous system at early time points. Mediat Inflamm. 2017;2017:7582437. https://doi.org/10.1155/2017/7582437. PubMed PMID: 28811681; PubMed Central PMCID: PMCPMC5547729.

166. Guarda G, Braun M, Staehli F, Tardivel A, Mattmann C, Forster I, et al. Type I interferon inhibits interleukin-1 production and inflammasome activation. Immunity. 2011;34(2):21323. https://doi.org/10.1016/j.immuni.2011.02.006. PubMed PMID: 21349431.

167. Miner JJ, Daniels BP, Shrestha B, Proenca-Modena JL, Lew ED, Lazear HM, et al. The TAM receptor Mertk protects against neuroinvasive viral infection by maintaining blood-brain barrier integrity. Nat Med. 2015;21(12):1464-72. https://doi.org/10.1038/nm.3974. PubMed PMID: 26523970; PubMed Central PMCID: PMCPMC4674389.

168. Gupta N, Rao PV. Transcriptomic profile of host response in Japanese encephalitis virus infection. Virol J. 2011;8:92. https://doi.org/10.1186/1743-422X-8-92. PubMed PMID: 21371334; PubMed Central PMCID: PMCPMC3058095.

169. Sharma A, Bhomia M, Honnold SP, Maheshwari RK. Role of adhesion molecules and inflammation in Venezuelan equine encephalitis virus infected mouse brain. Virol J. 2011;8:197. https://doi.org/10.1186/1743-422X-8-197. PubMed PMID: 21529366; PubMed Central PMCID: PMCPMC3113303.

170. Daniels BP, Jujjavarapu H, Durrant DM, Williams JL, Green RR, White JP, et al. Regionally distinct astrocyte interferon signaling promotes blood-brain barrier integrity and limits immunopathology during neurotropic viral infection. J Clin Invest. 2017 (in press).

171. Lai CY, Ou YC, Chang CY, Pan HC, Chang CJ, Liao SL, et al. Endothelial Japanese encephalitis virus infection enhances migration and adhesion of leukocytes to brain microvascular endothelia via MEK-dependent expression of ICAM1 and the CINC and RANTES chemokines. J Neurochem. 2012;123(2):250-61. https://doi.org/10.1111/j.1471-4159.2012.07889.x. PubMed PMID: 22845610.

172. Ruzek D, Salat J, Singh SK, Kopecky J. Breakdown of the blood-brain barrier during tickborne encephalitis in mice is not dependent on CD8+ T-cells. PLoS One. 2011;6(5):e20472. https://doi.org/10.1371/journal.pone.0020472. PubMed PMID: 21629771; PubMed Central PMCID: PMCPMC3100324.

173. Song M, Jin J, Lim JE, Kou J, Pattanayak A, Rehman JA, et al. TLR4 mutation reduces microglial activation, increases Abeta deposits and exacerbates cognitive deficits in a mouse model of Alzheimer's disease. J Neuroinflammation. 2011;8:92. https://doi.org/10.1186/1742-20948-92. PubMed PMID: 21827663; PubMed Central PMCID: PMCPMC3169468.

174. Song HY, Ryu J, Ju SM, Park LJ, Lee JA, Choi SY, et al. Extracellular HIV-1 Tat enhances monocyte adhesion by up-regulation of ICAM-1 and VCAM-1 gene expression via ROSdependent NF-kappaB activation in astrocytes. Exp Mol Med. 2007;39(1):27-37. https://doi. org/10.1038/emm.2007.4. PubMed PMID: 17334226.

175. Phares TW, Kean RB, Mikheeva T, Hooper DC. Regional differences in blood-brain barrier permeability changes and inflammation in the apathogenic clearance of virus from the central nervous system. J Immunol. 2006;176(12):7666-75. PubMed PMID: 16751414. 
176. Klein RS, Lin E, Zhang B, Luster AD, Tollett J, Samuel MA, et al. Neuronal CXCL10 directs CD8+ T-cell recruitment and control of West Nile virus encephalitis. J Virol. 2005;79(17):11457-66. https://doi.org/10.1128/JVI.79.17.11457-11466.2005. PubMed PMID: 16103196; PubMed Central PMCID: PMCPMC1193600.

177. Michalowska-Wender G, Losy J, Szczucinski A, Biernacka-Lukanty J, Wender M. Effect of methylprednisolone treatment on expression of sPECAM-1 and CXCL10 chemokine in serum of MS patients. Pharmacol Rep. 2006;58(6):920-3. PubMed PMID: 17220550.

178. Song L, Pachter JS. Monocyte chemoattractant protein-1 alters expression of tight junctionassociated proteins in brain microvascular endothelial cells. Microvasc Res. 2004;67(1):7889. PubMed PMID: 14709405.

179. Stamatovic SM, Shakui P, Keep RF, Moore BB, Kunkel SL, Van Rooijen N, et al. Monocyte chemoattractant protein-1 regulation of blood-brain barrier permeability. J Cereb Blood Flow Metab. 2005;25(5):593-606. https://doi.org/10.1038/sj.jcbfm.9600055. PubMed PMID: 15689955.

180. Moseman EA, McGavern DB. The great balancing act: regulation and fate of antiviral T-cell interactions. Immunol Rev. 2013;255(1):110-24. https://doi.org/10.1111/imr.12093. PubMed PMID: 23947351; PubMed Central PMCID: PMCPMC3748617.

181. Kim JV, Kang SS, Dustin ML, McGavern DB. Myelomonocytic cell recruitment causes fatal CNS vascular injury during acute viral meningitis. Nature. 2009;457(7226):191-5. https://doi.org/10.1038/nature07591. PubMed PMID: 19011611; PubMed Central PMCID: PMCPMC2702264.

182. Chai Q, He WQ, Zhou M, Lu H, Fu ZF. Enhancement of blood-brain barrier permeability and reduction of tight junction protein expression are modulated by chemokines/cytokines induced by rabies virus infection. J Virol. 2014;88(9):4698-710. https://doi.org/10.1128/ JVI.03149-13. PubMed PMID: 24522913; PubMed Central PMCID: PMCPMC3993813.

183. Phares TW, Fabis MJ, Brimer CM, Kean RB, Hooper DC. A peroxynitrite-dependent pathway is responsible for blood-brain barrier permeability changes during a central nervous system inflammatory response: TNF-alpha is neither necessary nor sufficient. J Immunol. 2007;178(11):7334-43. PubMed PMID: 17513784.

184. Johnson HL, Jin F, Pirko I, Johnson AJ. Theiler's murine encephalomyelitis virus as an experimental model system to study the mechanism of blood-brain barrier disruption. J Neurovirol. 2014;20(2):107-12. https://doi.org/10.1007/s13365-013-0187-5. PubMed PMID: 23857332; PubMed Central PMCID: PMCPMC3894260.

185. Suidan GL, Dickerson JW, Johnson HL, Chan TW, Pavelko KD, Pirko I, et al. Preserved vascular integrity and enhanced survival following neuropilin-1 inhibition in a mouse model of CD8 T cell-initiated CNS vascular permeability. J Neuroinflammation. 2012;9:218. https:// doi.org/10.1186/1742-2094-9-218. PubMed PMID: 22985494; PubMed Central PMCID: PMCPMC3489603.

186. Prakash MD, Munoz MA, Jain R, Tong PL, Koskinen A, Regner M, et al. Granzyme B promotes cytotoxic lymphocyte transmigration via basement membrane remodeling. Immunity. 2014;41(6):960-72. https://doi.org/10.1016/j.immuni.2014.11.012. PubMed PMID: 25526309.

187. Allingham MJ, van Buul JD, Burridge K. ICAM-1-mediated, Src- and Pyk2-dependent vascular endothelial cadherin tyrosine phosphorylation is required for leukocyte transendothelial migration. J Immunol. 2007;179(6):4053-64. PubMed PMID: 17785844.

188. Mittal M, Siddiqui MR, Tran K, Reddy SP, Malik AB. Reactive oxygen species in inflammation and tissue injury. Antioxid Redox Signal. 2014;20(7):1126-67. https://doi.org/10.1089/ ars.2012.5149. PubMed PMID: 23991888; PubMed Central PMCID: PMCPMC3929010.

189. Turowski P, Martinelli R, Crawford R, Wateridge D, Papageorgiou AP, Lampugnani MG, et al. Phosphorylation of vascular endothelial cadherin controls lymphocyte emigration. J Cell Sci. 2008;121(Pt 1):29-37. https://doi.org/10.1242/jcs.022681. PubMed PMID: 18096689; PubMed Central PMCID: PMCPMC3810954.

190. Gavard J, Gutkind JS. VEGF controls endothelial-cell permeability by promoting the betaarrestin-dependent endocytosis of VE-cadherin. Nat Cell Biol. 2006;8(11):1223-34. https:// doi.org/10.1038/ncb1486. PubMed PMID: 17060906. 
191. Monaghan-Benson E, Burridge K. The regulation of vascular endothelial growth factorinduced microvascular permeability requires $\mathrm{Rac}$ and reactive oxygen species. J Biol Chem. 2009;284(38):25602-11. https://doi.org/10.1074/jbc.M109.009894. PubMed PMID: 19633358; PubMed Central PMCID: PMCPMC2757962.

192. Konradt C, Ueno N, Christian DA, Delong JH, Pritchard GH, Herz J, et al. Endothelial cells are a replicative niche for entry of Toxoplasma gondii to the central nervous system. Nat Microbiol. 2016;1:16001. https://doi.org/10.1038/nmicrobiol.2016.1. PubMed PMID: 27572166 ; PubMed Central PMCID: PMCPMC4966557.

193. Medana IM, Turner GD. Human cerebral malaria and the blood-brain barrier. Int J Parasitol. 2006;36(5):555-68. https://doi.org/10.1016/j.ijpara.2006.02.004. PubMed PMID: 16616145.

194. Brown H, Rogerson S, Taylor T, Tembo M, Mwenechanya J, Molyneux M, et al. Blood-brain barrier function in cerebral malaria in Malawian children. Am J Trop Med Hyg. 2001;64(34):207-13. PubMed PMID: 11442219.

195. Hora R, Kapoor P, Thind KK, Mishra PC. Cerebral malaria - clinical manifestations and pathogenesis. Metab Brain Dis. 2016;31(2):225-37. https://doi.org/10.1007/s11011-0159787-5. PubMed PMID: 26746434.

196. Zougbede S, Miller F, Ravassard P, Rebollo A, Ciceron L, Couraud PO, et al. Metabolic acidosis induced by Plasmodium falciparum intraerythrocytic stages alters blood-brain barrier integrity. J Cereb Blood Flow Metab. 2011;31(2):514-26. https://doi.org/10.1038/ jcbfm.2010.121. PubMed PMID: 20683453; PubMed Central PMCID: PMCPMC3049507.

197. Pino P, Vouldoukis I, Dugas N, Hassani-Loppion G, Dugas B, Mazier D. Redox-dependent apoptosis in human endothelial cells after adhesion of Plasmodium falciparum-infected erythrocytes. Ann N Y Acad Sci. 2003;1010:582-6. PubMed PMID: 15033796.

198. Nacer A, Movila A, Sohet F, Girgis NM, Gundra UM, Loke P, et al. Experimental cerebral malaria pathogenesis - hemodynamics at the blood brain barrier. PLoS Pathog. 2014;10(12):e1004528. https://doi.org/10.1371/journal.ppat.1004528. PubMed PMID: 25474413; PubMed Central PMCID: PMCPMC4256476.

199. Nacer A, Movila A, Baer K, Mikolajczak SA, Kappe SH, Frevert U. Neuroimmunological blood brain barrier opening in experimental cerebral malaria. PLoS Pathog. 2012;8(10):e1002982. https://doi.org/10.1371/journal.ppat.1002982. PubMed PMID: 23133375; PubMed Central PMCID: PMCPMC3486917.

200. Machado FS, Desruisseaux MS, Nagajyothi, Kennan RP, Hetherington HP, Wittner M, et al. Endothelin in a murine model of cerebral malaria. Exp Biol Med (Maywood). 2006;231(6):1176-81. PubMed PMID: 16741072.

201. Dai M, Freeman B, Bruno FP, Shikani HJ, Tanowitz HB, Weiss LM, et al. The novel ETA receptor antagonist HJP-272 prevents cerebral microvascular hemorrhage in cerebral malaria and synergistically improves survival in combination with an artemisinin derivative. Life Sci. 2012;91(13-14):687-92. https://doi.org/10.1016/j.lfs.2012.07.006. PubMed PMID: 22820174; PubMed Central PMCID: PMCPMC3523882.

202. de Souza JB, Hafalla JC, Riley EM, Couper KN. Cerebral malaria: why experimental murine models are required to understand the pathogenesis of disease. Parasitology. 2010;137(5):75572. https://doi.org/10.1017/S0031182009991715. PubMed PMID: 20028608.

203. Li J, Chang WL, Sun G, Chen HL, Specian RD, Berney SM, et al. Intercellular adhesion molecule 1 is important for the development of severe experimental malaria but is not required for leukocyte adhesion in the brain. J Investig Med. 2003;51(3):128-40. https://doi.org/10.1136/ jim-51-03-15. PubMed PMID: 12769195.

204. Howland SW, Poh CM, Renia L. Activated brain endothelial cells cross-present malaria antigen. PLoS Pathog. 2015;11(6):e1004963. https://doi.org/10.1371/journal.ppat.1004963. PubMed PMID: 26046849; PubMed Central PMCID: PMCPMC4457820.

205. Haque A, Best SE, Unosson K, Amante FH, de Labastida F, Anstey NM, et al. Granzyme B expression by $\mathrm{CD} 8+\mathrm{T}$ cells is required for the development of experimental cerebral malaria. J Immunol. 2011;186(11):6148-56. https://doi.org/10.4049/jimmunol.1003955. PubMed PMID: 21525386. 
206. Huggins MA, Johnson HL, Jin F, N Songo A, Hanson LM, LaFrance SJ, et al. Perforin expression by CD8 T cells is sufficient to cause fatal brain edema during experimental cerebral malaria. Infect Immun. 2017;85(5) https://doi.org/10.1128/IAI.00985-16. PubMed PMID: 28264905; PubMed Central PMCID: PMCPMC5400849.

207. Swanson PA, 2nd, Hart GT, Russo MV, Nayak D, Yazew T, Pena M, et al. CD8+ T cells induce fatal brainstem pathology during cerebral malaria via luminal antigen-specific engagement of brain vasculature. PLoS Pathog 2016;12(12):e1006022. doi: https://doi.org/10.1371/journal. ppat.1006022. PubMed PMID: 27907215; PubMed Central PMCID: PMCPMC5131904.

208. Van den Steen PE, Deroost K, Van Aelst I, Geurts N, Martens E, Struyf S, et al. CXCR3 determines strain susceptibility to murine cerebral malaria by mediating $\mathrm{T}$ lymphocyte migration toward IFN-gamma-induced chemokines. Eur J Immunol. 2008;38(4):1082-95. https://doi. org/10.1002/eji.200737906. PubMed PMID: 18383042.

209. Claser C, Malleret B, Gun SY, Wong AY, Chang ZW, Teo P, et al. CD8+ T cells and IFNgamma mediate the time-dependent accumulation of infected red blood cells in deep organs during experimental cerebral malaria. PLoS One. 2011;6(4):e18720. https://doi. org/10.1371/journal.pone.0018720. PubMed PMID: 21494565; PubMed Central PMCID: PMCРMC3073989.

210. Teo TH, Howland SW, Claser C, Gun SY, Poh CM, Lee WW, et al. Co-infection with Chikungunya virus alters trafficking of pathogenic CD8(+) T cells into the brain and prevents Plasmodium-induced neuropathology. EMBO Mol Med. 2018;10(1):121-38. https:// doi.org/10.15252/emmm.201707885. PubMed PMID: 29113976; PubMed Central PMCID: PMCPMC5760855.

211. Feustel SM, Meissner M, Liesenfeld O. Toxoplasma gondii and the blood-brain barrier. Virulence. 2012;3(2):182-92. https://doi.org/10.4161/viru.19004. PubMed PMID: 22460645; PubMed Central PMCID: PMCPMC3396697.

212. Ueno N, Harker KS, Clarke EV, McWhorter FY, Liu WF, Tenner AJ, et al. Real-time imaging of Toxoplasma-infected human monocytes under fluidic shear stress reveals rapid translocation of intracellular parasites across endothelial barriers. Cell Microbiol. 2014;16(4):580-95. https://doi.org/10.1111/cmi.12239. PubMed PMID: 24245749; PubMed Central PMCID: PMCPMC4141879.

213. Sa Q, Ochiai E, Sengoku T, Wilson ME, Brogli M, Crutcher S, et al. VCAM-1/alpha4beta1 integrin interaction is crucial for prompt recruitment of immune $\mathrm{T}$ cells into the brain during the early stage of reactivation of chronic infection with Toxoplasma gondii to prevent toxoplasmic encephalitis. Infect Immun. 2014;82(7):2826-39. https://doi.org/10.1128/ IAI.01494-13. PubMed PMID: 24752515; PubMed Central PMCID: PMCPMC4097612.

214. Estato V, Stipursky J, Gomes F, Mergener TC, Frazao-Teixeira E, Allodi S, et al. The neurotropic parasite toxoplasma gondii induces sustained neuroinflammation with microvascular dysfunction in infected mice. Am J Pathol. 2018;188(11):2674-87. https://doi.org/10.1016/j. ajpath.2018.07.007. PubMed PMID: 30121257.

215. Silva NM, Manzan RM, Carneiro WP, Milanezi CM, Silva JS, Ferro EA, et al. Toxoplasma gondii: the severity of toxoplasmic encephalitis in C57BL/6 mice is associated with increased ALCAM and VCAM-1 expression in the central nervous system and higher blood-brain barrier permeability. Exp Parasitol. 2010;126(2):167-77. https://doi.org/10.1016/j.exppara.2010.04.019. PubMed PMID: 20434443.

216. Clark RT, Nance JP, Noor S, Wilson EH. T-cell production of matrix metalloproteinases and inhibition of parasite clearance by TIMP-1 during chronic Toxoplasma infection in the brain. ASN Neuro. 2011;3(1):e00049. https://doi.org/10.1042/AN20100027. PubMed PMID: 21434872; PubMed Central PMCID: PMCPMC3024837.

217. Dincel GC, Atmaca HT. Nitric oxide production increases during Toxoplasma gondii encephalitis in mice. Exp Parasitol. 2015;156:104-12. https://doi.org/10.1016/j.exppara.2015.06.009. PubMed PMID: 26115941. 
218. Masocha W, Kristensson K. Human African trypanosomiasis: how do the parasites enter and cause dysfunctions of the nervous system in murine models? Brain Res Bull. 2019;145:18. https://doi.org/10.1016/j.brainresbull.2018.05.022. PubMed PMID: 29870779.

219. Laperchia C, Palomba M, Seke Etet PF, Rodgers J, Bradley B, Montague P, et al. Trypanosoma brucei invasion and T-cell infiltration of the brain parenchyma in experimental sleeping sickness: timing and correlation with functional changes. PLoS Negl Trop Dis. 2016;10(12):e0005242. https://doi.org/10.1371/journal.pntd.0005242. PubMed PMID: 28002454; PubMed Central PMCID: PMCPMC5217973.

220. Mogk S, Meiwes A, Shtopel S, Schraermeyer U, Lazarus M, Kubata B, et al. Cyclical appearance of African trypanosomes in the cerebrospinal fluid: new insights in how trypanosomes enter the CNS. PLoS One. 2014;9(3):e91372. https://doi.org/10.1371/journal.pone.0091372. PubMed PMID: 24618708; PubMed Central PMCID: PMCPMC3950183.

221. Sternberg JM, Rodgers J, Bradley B, Maclean L, Murray M, Kennedy PG. Meningoencephalitic African trypanosomiasis: brain IL-10 and IL-6 are associated with protection from neuroinflammatory pathology. J Neuroimmunol. 2005;167(1-2):81-9. https://doi.org/10.1016/j. jneuroim.2005.06.017. PubMed PMID: 16054238.

222. Courtioux B, Boda C, Vatunga G, Pervieux L, Josenando T, M'Eyi PM, et al. A link between chemokine levels and disease severity in human African trypanosomiasis. Int $\mathrm{J}$ Parasitol. 2006;36(9):1057-65. https://doi.org/10.1016/j.ijpara.2006.04.011. PubMed PMID: 16765963.

223. Medeiros NI, Fares RC, Franco EP, Sousa GR, Mattos RT, Chaves AT, et al. Differential expression of matrix metalloproteinases 2, 9 and cytokines by neutrophils and monocytes in the clinical forms of chagas disease. PLoS Negl Trop Dis. 2017;11(1):e0005284. https://doi. org/10.1371/journal.pntd.0005284. PubMed PMID: 28118356; PubMed Central PMCID: PMCPMC5261563.

224. Olivera GC, Ren X, Vodnala SK, Lu J, Coppo L, Leepiyasakulchai C, et al. Nitric oxide protects against infection-induced neuroinflammation by preserving the stability of the blood-brain barrier. PLoS Pathog. 2016;12(2):e1005442. https://doi.org/10.1371/journal. ppat.1005442. PubMed PMID: 26915097; PubMed Central PMCID: PMCPMC4767601.

225. Amin DN, Rottenberg ME, Thomsen AR, Mumba D, Fenger C, Kristensson K, et al. Expression and role of CXCL10 during the encephalitic stage of experimental and clinical African trypanosomiasis. J Infect Dis. 2009;200(10):1556-65. https://doi.org/10.1086/644597. PubMed PMID: 19827943.

226. Grab DJ, Garcia-Garcia JC, Nikolskaia OV, Kim YV, Brown A, Pardo CA, et al. Protease activated receptor signaling is required for African trypanosome traversal of human brain microvascular endothelial cells. PLoS Negl Trop Dis. 2009;3(7):e479. https://doi. org/10.1371/journal.pntd.0000479. PubMed PMID: 19621073; PubMed Central PMCID: PMCPMC2707606.

227. Siddiqui R, Emes R, Elsheikha H, Khan NA. Area 51: how do Acanthamoeba invade the central nervous system? Trends Parasitol. 2011;27(5):185-9. https://doi.org/10.1016/j. pt.2011.01.005. PubMed PMID: 21507718.

228. Khan NA, Siddiqui R. Acanthamoeba affects the integrity of human brain microvascular endothelial cells and degrades the tight junction proteins. Int J Parasitol. 2009;39(14):16116. https://doi.org/10.1016/j.ijpara.2009.06.004. PubMed PMID: 19580812.

229. Jayasekera S, Matin A, Sissons J, Maghsood AH, Khan NA. Balamuthia mandrillaris stimulates interleukin-6 release in primary human brain microvascular endothelial cells via a phosphatidylinositol 3-kinase-dependent pathway. Microbes Infect. 2005;7(13):1345-51. https:// doi.org/10.1016/j.micinf.2005.05.001. PubMed PMID: 16027019.

230. Sissons J, Kim KS, Stins M, Jayasekera S, Alsam S, Khan NA. Acanthamoeba castellanii induces host cell death via a phosphatidylinositol 3-kinase-dependent mechanism. Infect Immun. 2005;73(5):2704-8. https://doi.org/10.1128/IAI.73.5.2704-2708.2005. PubMed PMID: 15845472; PubMed Central PMCID: PMCPMC1087316. 
231. Matin A, Siddiqui R, Jayasekera S, Khan NA. Increasing importance of Balamuthia mandrillaris. Clin Microbiol Rev. 2008;21(3):435-48. https://doi.org/10.1128/CMR.00056-07. PubMed PMID: 18625680; PubMed Central PMCID: PMCPMC2493082.

232. Baig AM. Pathogenesis of amoebic encephalitis: are the amoebae being credited to an 'inside job' done by the host immune response? Acta Trop. 2015;148:72-6. https://doi.org/10.1016/j. actatropica.2015.04.022. PubMed PMID: 25930186.

233. Alsam S, Sissons J, Jayasekera S, Khan NA. Extracellular proteases of Acanthamoeba castellanii (encephalitis isolate belonging to T1 genotype) contribute to increased permeability in an in vitro model of the human blood-brain barrier. J Infect. 2005;51(2):150-6. https://doi. org/10.1016/j.jinf.2004.09.001. PubMed PMID: 16038767.

234. Iqbal J, Naeem K, Siddiqui R, Khan NA. In vitro inhibition of protease-activated receptors 1,2 and 4 demonstrates that these receptors are not involved in an Acanthamoeba castellanii keratitis isolate-mediated disruption of the human brain microvascular endothelial cells. Exp Parasitol. 2014;145(Suppl):S78-83. https://doi.org/10.1016/j.exppara.2014.03.023. PubMed PMID: 24703976.

235. Lonsdale-Eccles JD, Grab DJ. Trypanosome hydrolases and the blood-brain barrier. Trends Parasitol. 2002;18(1):17-9. PubMed PMID: 11850009.

236. Sissons J, Alsam S, Goldsworthy G, Lightfoot M, Jarroll EL, Khan NA. Identification and properties of proteases from an Acanthamoeba isolate capable of producing granulomatous encephalitis. BMC Microbiol. 2006;6:42. https://doi.org/10.1186/1471-2180-6-42. PubMed PMID: 16672059; PubMed Central PMCID: PMCPMC1464133.

237. Shen L, Black ED, Witkowski ED, Lencer WI, Guerriero V, Schneeberger EE, et al. Myosin light chain phosphorylation regulates barrier function by remodeling tight junction structure. J Cell Sci. 2006;119(Pt 10):2095-106. https://doi.org/10.1242/jcs.02915. PubMed PMID: 16638813.

238. Kim BJ, Hancock BM, Bermudez A, Del Cid N, Reyes E, van Sorge NM, et al. Bacterial induction of Snail1 contributes to blood-brain barrier disruption. J Clin Invest. 2015;125(6):247383. https://doi.org/10.1172/JCI74159. PubMed PMID: 25961453; PubMed Central PMCID: PMCPMC4497739.

239. Ebrahimi CM, Sheen TR, Renken CW, Gottlieb RA, Doran KS. Contribution of lethal toxin and edema toxin to the pathogenesis of anthrax meningitis. Infect Immun. 2011;79(7):2510 8. https://doi.org/10.1128/IAI.00006-11. PubMed PMID: 21518787; PubMed Central PMCID: PMCPMC3191953.

240. Guichard A, McGillivray SM, Cruz-Moreno B, van Sorge NM, Nizet V, Bier E. Anthrax toxins cooperatively inhibit endocytic recycling by the Rab11/Sec15 exocyst. Nature. 2010;467(7317):854-8. https://doi.org/10.1038/nature09446. PubMed PMID: 20944747; PubMed Central PMCID: PMCPMC5831355.

241. Coureuil M, Lecuyer H, Scott MG, Boularan C, Enslen H, Soyer M, et al. Meningococcus Hijacks a beta2-adrenoceptor/beta-Arrestin pathway to cross brain microvasculature endothelium. Cell. 2010;143(7):1149-60. https://doi.org/10.1016/j.cell.2010.11.035. PubMed PMID: 21183077.

242. Coureuil M, Mikaty G, Miller F, Lecuyer H, Bernard C, Bourdoulous S, et al. Meningococcal type IV pili recruit the polarity complex to cross the brain endothelium. Science. 2009;325(5936):83-7. https://doi.org/10.1126/science.1173196. PubMed PMID: 19520910; PubMed Central PMCID: PMCPMC3980637.

243. Schubert-Unkmeir A, Konrad C, Slanina H, Czapek F, Hebling S, Frosch M. Neisseria meningitidis induces brain microvascular endothelial cell detachment from the matrix and cleavage of occludin: a role for MMP-8. PLoS Pathog. 2010;6(4):e1000874. https://doi. org/10.1371/journal.ppat.1000874. PubMed PMID: 20442866; PubMed Central PMCID: PMCPMC2861698.

244. Verma S, Kumar M, Gurjav U, Lum S, Nerurkar VR. Reversal of West Nile virus-induced blood-brain barrier disruption and tight junction proteins degradation by matrix metalloproteinases inhibitor. Virology. 2010;397(1):130-8. https://doi.org/10.1016/j.virol.2009.10.036. PubMed PMID: 19922973; PubMed Central PMCID: PMCPMC3102050. 
245. Louboutin JP, Strayer DS. Blood-brain barrier abnormalities caused by HIV-1 gp120: mechanistic and therapeutic implications. ScientificWorldJournal. 2012;2012:482575. https://doi.org/10.1100/2012/482575. PubMed PMID: 22448134; PubMed Central PMCID: PMCPMC3289936.

246. Chaves AJ, Vergara-Alert J, Busquets N, Valle R, Rivas R, Ramis A, et al. Neuroinvasion of the highly pathogenic influenza virus H7N1 is caused by disruption of the blood brain barrier in an avian model. PLoS One. 2014;9(12):e115138. https://doi.org/10.1371/journal. pone.0115138. PubMed PMID: 25506836; PubMed Central PMCID: PMCPMC4266681.

247. Hosseini S, Wilk E, Michaelsen-Preusse K, Gerhauser I, Baumgartner W, Geffers R, et al. Long-term neuroinflammation induced by influenza A virus infection and the impact on hippocampal neuron morphology and function. J Neurosci. 2018;38(12):3060-80. https://doi. org/10.1523/JNEUROSCI.1740-17.2018. PubMed PMID: 29487124.

248. Zhou Y, Lu ZN, Guo YJ, Mei YW. Favorable effects of MMP-9 knockdown in murine herpes simplex encephalitis using small interfering RNA. Neurol Res. 2010;32(8):801-9. https:// doi.org/10.1179/016164110X12644252260556. PubMed PMID: 20483026. 